\title{
PRIVATIZATION: IMPLICATIONS OF A SHIFT FROM STATE TO PRIVATE OWNERSHIP
}

\author{
Mislav Radić \\ London School of Economics and Political Science \\ Davide Ravasi \\ University College London \\ Kamal Munir \\ University of Cambridge
}

\begin{abstract}
Privatization - defined here as the transfer of ownership of state-owned organizations to private parties - has attracted the attention of scholars across multiple fields. Privatization programs have been based on the assumption, grounded in microeconomic theory, that a shift from public to private ownership will incentivize more efficient management of available resources. However, failure to deliver the expected outcomes in some cases, and the more nuanced perspective on state-ownership offered by recent research in management seem to challenge this assumption, calling for revisiting this literature. Our comparative review of existing studies suggests that the mixed results of privatization programs could be partly explained by what was privatized, how it was privatized, and the regulatory regime under which it was privatized. By doing so, our review provides conceptual clarity and structure to a rich but fragmented body of literature, making seemingly divergent findings more legible, outlining theoretical gaps, and identifying avenues for future exploration.
\end{abstract}

Accepted for publication in Journal of Management 
In the last four decades, through the sale of state-owned enterprises (SOEs), governments around the world have raised around $\$ 3.5$ trillion (The PB report, 2017). These divestitures were largely based on (or at least justified with) the general assumption that "the government is a bad owner" and the consequent belief that a shift from public to private ownership would yield efficiency gains (Megginson \& Netter, 2001).

These so-called privatization programs often gave rise to fierce public debates and employee strikes (Kaufmann \& Siegelbaum, 1997). In the long term, they also produced mixed results (Bachiller, 2017), thus reviving a debate among scholars and policy makers about private vs. public ownership (Estrin \& Pelletier, 2018; Ford \& Plimmer, 2019) and the contextual preconditions needed for their success (OECD, 2018). At the same time, rather than disappearing, as predicted by some (Spicer, McDermott, \& Kogut, 2000), many SOEs around the world have continued to thrive and are successfully competing with privately-owned ones (Bruton, Peng, Ahlstrom, Stan, \& Xu, 2015).

These observations have led many management researchers to move away from microeconomic theories postulating the inherent inefficiencies of SOEs (Laffont \& Tirole, 1991; Dharwadkar, George, \& Brandes, 2000) towards more nuanced understandings of privatization that draw attention to the various benefits of state ownership on capital investments (Inoue, Lazzarini, \& Musacchio 2013), international expansion (Estrin, Meyer, Nielsen, \& Nielsen, 2016), and innovation (Li, 2011). Such understandings frequently draw upon a host of general theories including public goods theory (Greenwald \& Stiglitz, 1986), agency theory (Meckling \& Jensen, 1976), and public choice theory (Dunleavy, 1986), that are used to illuminate various implications of private vs. state ownership and control (see the Online Appendix for an extensive discussion of these arguments).

These arguments are generally based on the assumption that publicly vs. privately owned organizations differ in their objectives, financing, resourcing, and management practices 
(Alford, 1993; Harrow \& Willcocks, 1990; Ring \& Perry, 1985). Privately owned enterprises (POEs) are generally assumed to pursue efficiency and prioritize profitability, while SOEs are expected to be driven by industrial and social policies, and to be more sensitive to the needs and expectations of a wider group of stakeholders. The appointment and compensation of managers in POEs, ideally, should reflect primarily their capacity to pursue the economic interests of shareholders; in SOEs these decisions often reflect political dynamics and concerns. SOEs are also believed to be able to rely, if necessary, on the deep pockets of the state or stateowned banks to fund long-term investments of uncertain return but deemed of public interests. The liquidation of a POE, finally, is determined by market forces (hence the importance of maintaining profitability), while for SOEs it is determined by political authorities (possibly leading to the long-term survival of otherwise inefficient firms).

Empirical evidence, however, suggests that, in privatized firms, ownership change did not always produce the expected results. In this review paper, we seek to make sense of seemingly conflicting findings in prior studies, by re-visiting the empirical and theoretical context in which they were carried out and propose a new research agenda based on a revised understanding of this highly significant phenomenon.

\section{PRIVATIZATION: AN OVERVIEW}

The term "privatization" is understood somewhat differently across different academic disciplines and institutional settings. Scholars in public administration (Moe, 1987), sociology (Marwell, 2004) and political science (Henig, 1990) generally adopt a broad definition, encompassing "all the reductions in the regulatory and spending activity of the state" (Savas, 2000, p.126). In management (Johnson, Smith, \& Codling, 2000), finance (Gupta, 2005) and economics (Megginson \& Netter, 2001), scholars tend to adopt a narrower definition referring exclusively to the "transfer of ownership of state-owned enterprises from the government to private parties" (Starr, 1988; Megginson \& Netter, 2001). 
Similarly, in countries characterized by a limited number of SOEs (e.g., the United States), privatization is often used to describe activities that many scholars refer to as privatization by delegation (Savas, 2000, p.127), understood as the full or partial transfer, to a private entity, of a service previously delivered by the government, while retaining oversight of activities and results. Delegation is often implemented through contracting out, a form of privatization in which local governments outsources to private companies' services, such as solid-waste collection, street repair, street cleaning etc., that were previously provided by public sector organizations. Another widely used type of delegation is franchising (Savas, 1992) - a term that designates an agreement under which governments award private organizations the (often exclusive) right to deliver a regulated service, such as public transportation, previously provided by state-run organizations (Yarrow, 1986; Savas, 1992).

On the other hand, in countries with a tradition of direct intervention of the state in the economy (e.g. post-socialist countries, and Western European countries), the term privatization often refers to the transfer of the ownership of public organizations from the state to private actors - also referred to as privatization through divestment (Savas, 2000, p.127). This usage is consistent with early definitions of this term in economics (Yarrow, 1986; Vickers \& Yarrow, 1991). This type of privatization can vary in degrees, ranging from minority, majority, to full privatization - depending on whether the government decides to retain a majority or minority stake in the capital, or no stake at all (OECD, 2018).

Privatization through divestment can be executed using different methods - the most common being the full or partial sale of the shares of an SOE to private investors through an initial public offering (IPO). This method has received the widest attention as it tends to be used for the largest SOEs (Estrin \& Pelletier, 2018). Other, less common, methods include the direct sale (acquisition) of the SOE to a single investor (Bennett, Estrin, Maw \& Urga, 2003) - favored in countries where capital markets are less developed (Estrin \& Pelletier, 2018) - 
and management or employee buyouts (Wright, Hoskisson, Busenitz, \& Dial, 2000), whereby the enterprise is sold directly to its employees or (more often) to its managers.

Divestment could also be accomplished through the donation of shares to particular beneficiaries (Savas, 2000, p.129). Employee stock-ownership plans, for instance, are used to transfer a percentage of shares to employees (Palcic \& Reves, 2011; Wright, Buck, Filatotchev, 2002), often in conjunction with other privatization methods (e.g. IPOs). Many privatizations in central and eastern Europe were conducted by distributing to the general public vouchers representing potential shares in the SOEs (Bennet, Estrin, \& Urga, 2007; Boycko, Shleifer, \& Vishny, 1994). Finally, in rare cases, SOEs may even be donated to key stakeholders (e.g. users of the service), usually organized through a non-profit organization or trust (Savas, 2000, p.139).

Theoretically a review could consider the entire body of work on all forms of privatization; practically, however, it would be a challenging task. Consistent with the current usage of the term in management studies, our review focused on privatization through divestment understood as the full or partial transfer of ownership of state-owned organizations to private entities. It spanned, however, several academic disciplines, including management, economics, public administration, finance, sociology and political science (see the Online Appendix for details of our methodology and the full list of papers we reviewed).

Our review led us to organize past studies into four broad macro-areas: antecedents (literature examining the factors that lead to the decision to privatize), outcomes (literature focusing on the outcome of privatization), mediating processes (organizational changes associated with privatization that generate the observed outcomes), and moderators (internal and external factors that affect its outcomes) (see Figure 1 for an overview). Based on a comparison of seemingly divergent findings in each area, we argue that mixed results in prior studies can partly be explained by variation in what was privatized (commercial enterprises vs. 
public service providers), how it was privatized (e.g. fully vs. partially), and the institutional context (e.g. regulatory regimes, macroeconomic situation) within which privatization occurred. These differences - our review suggests - influence organizational change trajectories and the economic outcomes of privatization.

---- Insert Figure 1 about here ----

\section{ANTECEDENTS: WHY DO GOVERNMENTS PRIVATIZE?}

A stream of research on privatization has focused on its antecedents. Rather than seeking empirical support for arguments in favor (or against) privatization, these studies have tried to explain what led governments to privatize SOEs in the first place. The factors that they identified can be broadly grouped into country-level determinants and firm-level determinants.

\section{Country-Level Determinants}

As the number of privatizations around the world increased, scholars explored factors that explain the relative propensity of governments to privatize. These factors can be broadly divided into economic and socio-political.

Economic factors. Based on the assumption that privatization can be used to lower government debt, Ramamurti (1992) showed that privatization was more likely to be pursued by governments with higher budget deficits and foreign debt; these were often developing economies that had "overused" SOEs in the past - i.e., countries that had introduced state ownership with "little justification on economic grounds" (p.229). Likewise, Biglaiser and Brown (2003) found that public sector debt significantly increased the rate of privatization in Latin American countries. Xu, Tihanyi and Hitt (2017), however, show that negotiations between local and central governments has a bearing on privatization decisions: privatization is more likely when local fiscal revenues are higher, as their steady budget may grant them more discretion to privatize assets. 
Socio-political factors. Some scholars have drawn attention to political factors that affect the likelihood of privatization. Biais and Perotti (2002), for instance, argued that privatization programs that allocate shares to middle-class voters can shift support away from left-wing parties whose policies might reduce the value of shareholdings. However, if privatizations are unpopular among voters, governments may be more reluctant to pursue them, especially in the presence of strong oppositions, or when firms are located in areas where political authorities cannot afford to lose consensus (Dinc \& Gupta, 2011). Other studies suggest how these decisions are affected by various forms of social influence. For instance, governments tend to emulate the privatization strategies of neighboring countries (Schmitt, 2011; Breen \& Doyle, 2013) or countries they perceive as similar (Fink, 2011). Similarly, multilateral agencies, such as the International Monetary Fund (Kentikelenis \& Babb, 2019), seem to influence decisions to privatize (Henisz, Zelner, \& Guillén, 2005; Breen \& Doyle, 2013).

\section{Firm-Level Determinants}

Based on the economic assumption that the primary purpose of privatization is to increase the efficiency of SOEs, some scholars have argued that low-performing SOEs are more likely to be privatized (Ramamurti, 1992; Guo \& Yao, 2005) because governments are unwilling or unable to provide the investments and close monitoring required to restore profitability in these companies (OECD, 2018). These arguments often cite research showing that the most inefficient firms experience the greatest improvements in efficiency (Claessens, Djankov, \& Pohl, 1997; Frydman, Gray Hessel, \& Rapaczynski, 1999). Governments concerned with maximizing efficiency - these studies conclude - should privatize the least efficient firms first.

In fact, other studies show that better performing SOEs are more likely to be privatized than worse performing ones (Dinc \& Gupta, 2011; Xu et al., 2017), suggesting that increasing efficiency is just one of several competing objectives for a government to pursue: while privatizing the best performing enterprises may be inconsistent with this objective, it may help 
maximize revenues earned from privatization and minimize the political cost of unemployment (Gupta, Ham, \& Svejnar, 2008).

\section{PRIVATIZATION OUTCOMES: HOW DOES PRIVATIZATION INFLUENCE ORGANIZATIONS?}

Arguments for privatization have been largely based on the assumption that a shift from state to private ownership would reorient managers towards the maximization of shareholders' wealth, which in turn will increase the efficiency of operations (Megginson \& Netter, 2001, 2003; Vickers \& Yarrow, 1991; see Online Appendix for more details). It is not surprising, then, that - as we discuss in this section - a large number of studies have explored how privatization influences financial and/or operating performance, trying to corroborate (or possibly disprove) arguments based on micro-economic theories. At the same time, others have examined other potential outcomes of privatization - such as quality of service, innovation internationalization, or employment levels.

\section{Financial and Operational Performance}

To date, more than 80 studies, the vast majority of which are grounded in agency theory, have empirically tested the impact of privatization on the financial performance of enterprises. Among these, earlier ones sought to compare the performance of state-owned companies and private companies (not - importantly - privatized ones). Some studies used single-country (e.g. Majumdar, 1996; Tian, 2000) or single-industry samples (e.g. Ehrlich, Gallais-Hamonno, Liu, \& Lutter; 1994; Galal, Jones, Tandon, \& Vogelsang, 1994) to examine costs and productivity growth of private and state-owned firms over a period, while others used multi-industry and multi-national time-series comparisons to analyze correlations between state and private ownership and efficiency (e.g. Boardman \& Vining, 1989, Frydman et al., 1999). Collectively, these studies seemed to support economic arguments for privatization by pointing to the superior performance of private vs. state-owned enterprises. Their methodology, however, has 
been criticized (e.g. Estrin, Hanousek, Kocenda, \& Svejnar, 2009; Megginson \& Netter, 2001), because single-industry studies included samples from different countries, but did not control for country-level differences (e.g. level of economic development) that might have influenced the performance of enterprises. Direct comparisons between public and private firms might also have been biased by endogeneity and selection effects, as factors that determine the choice to privatize a firm could also influence performance (Gupta et al., 2008). For instance, singlecountry studies may fail to consider that in certain industries, firms may be owned by the state because of market failure (Megginson \& Netter, 2001) and the choice of public vs. private ownership itself is endogenous to both political (e.g. provision of free public services) and performance goals (Megginson \& Sutter, 2006). Conscious of these methodological issues, later studies (e.g. Goldeng, Grunfeld, \& Benito, 2008; Hartley \& Medlock, 2013) were not presented explicitly as research on the outcome of privatization, but only mentioned the indirect relevance of their findings for scholars interested in privatizations.

A second group of studies examined more directly the impact of privatization on performance, by comparing performance data (e.g. sales, income) pre-and post-privatization. Most of these studies compared performance before and after the initial public offering (IPO) in share-issue-privatizations (e.g. Munir \& Naqvi, 2017). Research using this approach either focused on specific industries (e.g. D’Souza \& Megginson, 1999) or countries (e.g. Maquieira \& Zurita, 1996; Sun \& Tong, 2003), or used a sample that combined multiple industries and countries (Megginson, Nash, \& van Randenborgh, 1994). Other scholars focused on specific types of divestment such as direct sale to private investors (e.g. Uhlenbruck \& Castro, 1998, 2000) and voucher privatizations (e.g. Boycko et al., 1994; Nelson \& Kuzes, 1994).

This second group of studies offers a more mixed portrayal of the impact of privatization on performance. While most studies point to improvements in company performance postprivatization, several others question this idea $^{1}$ (Bachiller, 2017; Estrin \& Pelletier, 2018; 
Megginson, 2017). A comparative analysis of this work suggests that these results can be partly explained by the characteristics of the industry (in particular, the relative competitiveness of the market), by the method that was used to privatize, and by the institutional context within which privatization took place.

Market competitiveness (after privatization) and post-privatization performance. 45 of the 81 papers that empirically tested the privatization-performance relationship used samples of firms from multiples industries without considering the potential influence of industryspecific factors on performance. A closer examination of the remaining 36, however, reveals that research showing improved financial performance was mostly conducted on privatized commercial enterprises operating in competitive markets (e.g. Boubakri, Cosset, Fischer, \& Guedhami, 2005; Megginson \& Netter, 2001). This was the case, for instance, of all the twelve studies investigating the banking sector (e.g. Azam, Biais, \& Dia, 2004; Bonin, Hasan, \& Wachtel, 2005), and the majority of research on the privatization of manufacturing firms (e.g. Xia \& Walker, 2015), airlines (e.g. Eckel, Eckel, \& Singal,1997) and pharmaceutical companies (e.g. Xu et al., 2017).

In contrast, research on the privatization of former public-service providers, such as electricity (e.g. Balza, Jimenez, \& Mercado, 2013; Kirkpatrick, Parker, \& Zhang, 2006), telecom (e.g. Bortolotti, D’Souza, Fantini, \& Megginson, 2002; Gasmi, Maingard, Noumba, \& Virto, 2013), and water (e.g. Ogden \& Watson, 1999; Estache \& Rossi, 2002) displayed mixed results. A study of privatized Colombian power generators, for instance, found that, once other factors were accounted for, performance improvement was not systematically associated with ownership change (Pombo \& Ramirez-Gomez, 2005). While Newbery and Pollitt (1997) found improvements in the performance of privatized electricity utilities in the UK, a comprehensive analysis of 36 countries, showed no significant improvements (Zhang, Parker, \& Kirkpatrick, 
2008). Similarly, while Sueyoshi (1998) highlighted enhanced performance in the telecom sector, Wallsten (2001) found that privatization had few benefits.

These observations suggest that post-privatization, firms operating in markets where a combination of technological affordances and regulatory provisions ensure intense competition can no longer count on the state to buffer the impact of inefficiencies and need to restructure their operations and improve their performance if they want to survive. Conversely, where technological constraints or political support enables the newly privatized firm to continue operating de facto in conditions of monopoly or quasi-monopoly, there will be fewer incentives to improve. In the absence of structural and regulatory conditions to enable and stimulate competition, ownership change alone may be insufficient to foster efficiency gains, which may explain why some privatizations seem to be more successful than others on this front (Vining \& Bordman, 1992; Uhlenbruck \& Castro, 2000).

Not all governments, however, have been equally successful at creating a competitive environment. In the case of electricity, for instance, some governments granted independent agencies executive powers of setting tariffs and regulating entry, generally leading to performance improvements in privatized firms (Bortolotti et al., 2002; Cubbin \& Stern, 2006). Conversely, to the extent that governments continued to consider certain industries, such as water supply, of public interest, and enforced strict regulatory regimes to assure the quality and accessibility of the service, privatized enterprises enjoyed less discretion to refocus their objectives and reconfigure their operations to increase profitability. At the same time, Munir and Naqvi's (2017) study of the privatization of banks in Pakistan shows how an excessively lax regulatory regime may not be desirable either, as it may allow privatized firms to increase their profitability at the expense of public good.

Privatization method and post-privatization performance. Some degree of divergence in findings is also explained by the method used to privatize. Past studies have examined 
various methods of transferring public ownership, such as IPO (e.g. D’Souza, Megginson, \& Nash, 2005; Vaaler \& Schrage, 2009), acquisitions (e.g. Meyer, 2002; Uhlenbruck \& Castro, 2000), and vouchers (e.g. Claessens \& Djankov, 1999; Harper, 2002). A comparison of studies exploring different methods suggests that privatization through IPO seems to show stronger improvements in financial performance than other methods (Bachiller, 2017; Estrin et al, 2009) $)^{2}$. Scholars have explained this observation with the beneficial effects of the discipline of capital markets (Jones, Megginson, Nash, \& Netter, 1999), arguing that where capital markets are well-functioning (Megginson, 2005) the threat of takeover will lead to increased managerial effort and accountability (Arcas \& Bachiller, 2010; D’Souza, Megginson, \& Nash, 2001). The fact that these conditions are not always met may partly explain the observed variance in the comparative performance of privatization through IPO. A study of transitional economies, for instance, showed how - when capital markets are relatively underdeveloped - this method may not deliver significantly better results than others (Bennett et al., 2007).

Institutional context and post-privatization performance. Mixed results about the comparative superiority of IPOs point to a third factor potentially influencing the privatizationperformance relationships, that is the characteristics of the institutional context in which privatization occurred.

Early studies examined privatizations in the United Kingdom under Margaret Thatcher (e.g. Martin \& Parker, 1995; Morley, 1986), then continental Europe (e.g. Berne \& Pogorel, 2006; Dyck, 1997) and Latin America (e.g. Aggarwal, Leal, \& Hernandez, 1993; Wallsten, 2001), followed by the transition to capitalism in Russia (e.g. Earle \& Estrin, 2003; Jones, 1998; Sachs, 1992) and other Central-Eastern European countries (e.g. Harper, 2002; Smith, Cin, \& Vodovopivec, 1997), and, more recently, China (e.g. Huang \& Wang, 2011; Liao, Liu, \& Wang, 2011; Sun \& Tsong, 2003). 
Scholars usually distinguished these contexts in terms the level of economic development of the country (Ramamurti, 2000; Megginson \& Sutter, 2006), thus contrasting "developed" (D’Souza et al., 2005), and “developing” (Megginson \& Sutter, 2006) or "transitional” economies (Estrin et al., 2009). Some scholars argued that in developing economies, underdeveloped institutional infrastructure, governance mechanisms, and property rights enforcements may prevent private ownership to fully display its beneficial effects (Dharwadkar et al., 2000; Filatotchev, Wright, Uhlenbruck, Tihanyi, 2003). A recent meta-analysis (Bachiller, 2017), however, noted that privatized companies actually seem to perform better in developing rather than developed economies, possibly because of the benefits of no longer being under the influence of intrusive or resource-deprived governments.

Given that variation in results - even within developed and developing countries - is substantial, this classification may be failing to capture important contextual differences. In fact, research in institutional economics (Hall \& Soskice, 2001) and international business (Fainshmidt, Judge, Aguilera, \& Smith, 2018) points out that the variety of (capitalist) economic systems is far more nuanced. Our review suggests that this variety may influence the outcome of privatization by affecting organizational processes leading to change (or lack thereof) in managerial behavior, and the impact of choices about the method and degree of privatization, which prior research highlighted as important moderators of the privatizationperformance relationship. Because of this reason, we discuss the influence of the institutional context in greater detail when presenting these two macro-areas of research.

\section{Service Quality}

The general argument in favor of state-ownership of utilities like electricity, railway and water providers is that governments could use it to address market failures that may lead to the suboptimal provision of these essential services. Despite this fact, proponents of privatization have argued that the inherent inefficiency of SOEs is often so high that a shift to private 
ownership would not only lead to higher financial performance, but also to higher service quality. For instance, Ogden and Watson (1999) claimed that, when water supply was privatized in the UK, improving service quality initially affected negatively current profits, but shareholder returns eventually increased in the long term.

Most studies, however, question the idea that privatization had any impact on service quality, and argue instead that improvements in quality are related instead to better regulation (Dore, Kushner and Zummer, 2004; Estache, Rossi, \& Ruzier, 2004; Silvestre, Hall, Matos, Figueira, 2010). For instance, Kirkpatrick, Parker, and Zhang (2006) found no significant quality differences between state-owned and privatized water providers in Africa. Similarly, research on privatized electricity providers (e.g., Bortolotti, Fantini, \& Sinascalco, 1998; Zhang, Parker, \& Kirkpatrick, 2008) showed that market liberalization and effective regulation, rather than privatization per se, led to an in increase in quality and output of electricity generation. To do so, these studies argued, it is important to develop an independent regulator (Spiller, 1996), unbundle generation from transmission (Pollitt, 2008) and expand legal access to the transmission network (Bortolotti et al., 2002). These observations are in line with Hart, Shleifer \& Vishny's (1997) argument that, if contracts are incomplete - because the quality of service a government wants can never be fully specified - private providers of public services may tend to reduce cost (and quality) excessively because they ignore the adverse effect of non-contractible quality (see Online appendix).

It is also important to note that the nature of the certain services restricts the potential for competition, which scholars consider essential to induce providers to improve quality in order to attract customers (Kirkpatrick et al., 2006). While technological advancements have enabled competition in services like telecommunications and electricity, it is less possible to do so in services like water provision. In these cases, scholars have argued for the importance of competitive processes to win contracts or concession agreements (Estrin \& Pelletier, 2018), 
and warned about the high transaction costs that may be associated with contracting the provision of services in what are essentially monopolistic conditions (Kirkpatrick et al., 2006).

\section{Innovation}

Industrial policy arguments in favor of state ownership highlighted the benefits of the deep pockets of the state for research and development, especially in areas where discovery costs are high (Musacchio \& Lazzarini, 2014, p.59). Research has shown, however, that newly privatized firms often reduce the amount of resources devoted to $R \& D$, while at the same time increasing the efficiency of their research, measured in terms of the amount and quality of the patents they produce (Munari \& Oriani 2005; Munari, Roberts \& Sobrero 2002; Munari \& Sobrero 2003). These results have been explained by the argument that a shift from state to private ownership would lead to a reorientation of R\&D programs toward innovation outputs that are commercially more applicable (Belloc, 2014). Importantly, however, research has also shown that privatization may not have an immediate impact on $R \& D$ performance, but this impact may manifest over a long period of time (Munari \& Oriani, 2005).

\section{Internationalization}

Some privatization proponents argued that the transformative changes and entrepreneurial mindset brought about by privatization will actually foster investments in innovation to support strategic change and internationalization (Zahra, Ireland, Gutierrez, \& Hitt, 2000). Indeed, when, in Europe, the telecommunications sector was privatized through the 1980s and 1990s, a number of prior SOEs emerged as large multinational players (Bortolotti et al., 2002). A study of the 22 largest telecom companies in the OECD, however, found that private ownership did not significantly explain internationalization patterns (Alonso, Clifton, Diaz-Fuentes, Fernandez-Gutierrez, \& Revuelta, 2013). A similar study of the electricity and telecom sectors in the EU found no support for the relationship between privatization and internationalization (Clifton, Diaz-Fuentes \& Revuelta, 2010). These findings, therefore, seem to contradict 
arguments advanced by both scholars (Zahra et al., 2000) and policymakers (OECD, 2003), and suggest instead that, to the extent that a state-owned firm operates in a competitive market, its propensity to internationalize will be comparable to privately-owned ones.

\section{Employment}

Finally, some studies tested the implicit prediction from agency theory that privatization would lead to lower employment levels, because - no longer constrained by social and political goals - privatized firms would be free to operate more efficiently and eliminate excess workforce (Musacchio \& Lazzarini, 2014, p.36; Hodge, 2000, p.44). Research findings, again, are mixed. Bhaskar and Khan (1995), for instance, found that privatization of the jute industry in Bangladesh significantly decreased employment levels. Similarly, La Porta and Lopez-deSilanes (1999) found that, in Mexico, privatized firms reduced employment by half, while the remaining workers saw a significant pay rise. In contrast, Gupta (2011) showed that, in India, privatization significantly increased employment in the long run and was not associated with decline in employee compensation. Similarly, a global sample of companies privatized in the 1980s, also presented an increase in employment levels (Megginson et al., 1994).

A potential explanation for such mixed findings could be found in unmeasured contingencies and the temporal lag of such studies. For instance, Hodge (2000) points out that Megginson and colleagues (1994) did not control for the fact that the significant increase in headcount at British Airways was due to the acquisition of a large competitor. This suggests that, even if employment levels initially drop as privatized firms restructure and streamline operations, they may eventually recover, spurred by commercial success and growth strategies (Estrin \& Pelletier, 2018) as these firms become more efficient and alert to entrepreneurial opportunities (Zahra et al., 2000). 


\section{MEDIATING PROCESSES OF PRIVATIZATION}

Research on the outcomes of privatization did not really investigate internal consequences of the sale of state-owned organizations to private investors. To the extent that private ownership seemed to be associated with higher performance, they assumed that changes in goal setting, incentive systems, and decision-making reflected predictions from micro-economic theory. Spurred by the apparent inconsistency between theoretical predictions and observed outcomes, a third group of studies, often using qualitative methods, examined more closely the organizational changes that privatization brought about in formerly state-owned firm. We refer to these studies as investigating mediating processes, because they helped illuminate how the transfer of ownership from the state to private entities produced the observed outcomes by affecting incentive systems, managerial attitudes, organizational structure and culture. While some of these studies supported the idea that privatization would realign incentive systems (e.g., Rodríguez et al., 2007), change organizational culture (e.g., Ross, 2008), and stimulate entrepreneurial orientation (e.g., Wu et al., 2008), others reported cases in which privatization had only a limited impact on the organization.

\section{Change in Incentive Systems}

Agency theory posits that a shift from state to private ownership would change the structure of incentives within the organization. In support to this theory, Rodriguez, Espejo and Cabrera (2007) showed how changing agency relations led to redesign incentive system in a privatized Spanish electricity provider, increasing the relevance of profitability and financial control. A study of UK privatized firms similarly revealed substantive changes in managerial incentives after these firms transitioned to private ownership (Cragg \& Dyck, 2003).

Other studies, however, question the assumptions of agency theory. Two separate studies of privatized Hungarian enterprises, for instance, showed that private owners would not necessarily implement radically different incentive policies from state controllers (Whitley \& 
Czaban, 1998, Czaban \& Whitley, 2000). Uncertainty around state policies on privatization, the authors argued, limited the capacity for major structural and strategic change in privatized organizations, and the new owners were hesitant to delegate major responsibilities until they developed a better understanding of the privatized organization and trust in their managers.

\section{Change in Management}

Early research on privatization assumed that transferring ownership from public to private would lead to better management, as new managers would be more competent and commercially oriented (Ogden, 1995). For instance, by studying privatizations in Taiwan, Wu, $\mathrm{Su}$ and Lee (2008) found that privatization led to an increased entrepreneurial orientation among employees. However, when studying privatized Czech organizations, Soulsby and Clark (1996) observed that, although Czech managers were influenced by commercially oriented western-style management practices, their behavior also reflected a strong national identity and a certain suspicion towards foreign business, as new managerial ideas were filtered through the lens of the emerging post-communist management. Similarly, a study of the UK railway industry showed that, despite the prediction that privatization would lead to a "new breed" of managers (Boycko, Shleifer, \& Vishny,1996), the attitudes that characterized managers hired after the privatization and those that had been employed before did not differ

much (Pendleton, 2003). The design of the study, however, cannot exclude that this similarity is due to veteran managers having changed their attitudes after privatization, or managers more critical of privatization having left after the change (hence not being captured by the study).

\section{Change in Culture}

Arguments grounded in institutional theory propose that moving from state to private ownership would eventually introduce profound cultural changes, reflecting new conventions about the appropriate way to manage and govern an organization (Johnson et al., 2000). Indeed, a study of the privatization of Czech telecom operators revealed how, despite initial resistance 
by employees, privatization led indeed to change in organizational culture, thanks to the introduction of a new bonus systems, department restructuring, and workforce training (Ross, 2008). Similarly, Cunha and Cooper (2002) found that the privatization of three Portuguese firms led to "greater emphasis on performance, people orientation and organizational integration" (p.21.). On the other hand, research on the privatization of Czech state-owned enterprises (Clark \& Soulsby, 1995) highlighted the difficulties that managers encountered in breaking away from the cultural legacy of the past. Although organizational restructuring towards a divisional, decentralized structure was supported by a major investment in information technology, both senior and middle managers continued to operate with the hierarchical, top-down approach that had permeated the culture before privatization.

\section{Change in Organizational Structure}

Early privatization literature assumed that the sale to private investors would improve the organizational structure of "slow" and inefficient SOEs (e.g., Hammer, Hinterhuber, \& Lorenz, 1989) by making it more decentralized (Cuervo \& Villalonga, 2000), less hierarchical (Soulsby \& Clark, 1996) and more streamlined (Filatotchev, Buck, Zhukhov, 2000). Other studies, however, have questioned the necessity of ownership change to carry out such restructuring. Research shows that many privatized SOEs were really restructured prior to the actual privatization, which induced some scholars (e.g., Parker, 1997) to argue that the assumed benefits of privatization were evident even before the actual sale of an enterprise. For instance, a longitudinal study of the UK rail services showed that organizational change and performance improvements not only preceded the transfer of the railways from public to private ownership but were also a pre-requisite, without which privatization would have been less feasible for the government (Tyrrall \& Parker, 2005).

Institutional logics, market competitiveness (prior to privatization), and organizational change. Research exploring mediators in the influence of privatization has 
shown that former SOEs do not always change in ways predicted by micro-economic theories. When discussing research on post-privatization performance, we mentioned how market competitiveness after privatization seemed to positively influence financial and operating performance by incentivizing managers to pursue efficiency and profitability and enabling them to reap the benefits of improved quality. Not all newly privatized firms examined by prior studies, however, were equally used to operating in a competitive environment: while some had been operating in liberalized markets prior to privatization (e.g., Graham, 1997), others faced competition only after privatization, as their markets were deregulated and opened up to new entrants (e.g., Bognetti \& Obermann, 2008). Prior exposure to market competition, we suggest, may help explain why some formerly state-owned firms seem to be more receptive to organizational change than others.

Despite Vickers and Yarrow's (1991) early call to differentiate the analysis of privatizations based on the type of organization that was privatized, past studies rarely distinguished between the privatization of commercial enterprises operating in competitive markets and the privatization of public service providers. By commercial SOEs, we refer to organizations like banks (Bonin et al., 2005), industrial manufacturers (Gupta, 2005), or airlines (Al Jazzaf, 1999) that, for historical reasons, were state-owned, but operated in competitive markets. By public service providers, we refer to organizations - such as postal services, health care organizations, or electricity providers - that, for a combination of political choices, cultural, technical and economic factors, operated in non-market conditions and were generally regarded locally (and frequently regarded themselves) as delivering services deemed of public utility.

A comparison of 22 past studies suggests that this distinction may in fact help explain variation (or lack thereof) in change trajectories. The majority of research on the effect of privatization in commercial enterprises such as manufacturing firms, airlines and banks (e.g., Cunha \& Cooper, 2002; Wu et al., 2008; Grugulis \& Wilkinson, 2002) seems to support the 
prediction that privatization would lead to significant structural and cultural changes (Zahra et al, 2000). In contrast, research on privatized public-service providers, such as railways, electricity providers and water providers (Crockford, 1994; Pendleton, 2003; Tyrrall \& Parker, 2005; Dean, Carlisle, \& Baden-Fuller, 1999) frequently reported how privatization had limited impact on the internal administrative systems and operations.

An institutionalist perspective on privatization (see Online Appendix) may help us interpret these divergent patterns. According to institutional theorists, SOEs tend to be managed according to coherent sets of principles - which they refer to as "templates" (Johnson et al., 2000) or, more recently, "logics" (Greve \& Man Zhang, 2017) - that differ from those followed by private companies. State-owned firms, for instance, tend to pursue a broad range of goals, and prioritize access to service over profit margins and job creation over efficiency; political loyalty may also be a requirement for top positions. These differences reflect the fact that the former operate within the broader normative order of the state, whereas the latter are subjected to the broader normative order of the market (Friedland \& Alford, 1991).

Early research assumed that all state-owned organizations operated under a state (or publicsector) logic, while privately-owned ones followed a market (or business) logic (Bruton, Ahlstrom, \& Li, 2010), and that, after a temporary co-existence in the aftermath of privatization, the old public sector template would be replaced by a new business-oriented one (Johnson et al., 2000). In fact, recent research on SOEs suggests that, to the extent that these organizations operate as commercial enterprises in competitive markets (e.g. airlines companies, oil producers, etc.), their operations seem to follow a hybrid template that combines elements of state and market logics (Bruton et al., 2015; Koppell, 2007). This can be explained by their operating at the intersection of the two institutional orders of the state (because of their ownership) and the market (because of the structure of the industry they operate in). 
If we accept this idea, we can explain the comparatively higher propensity of privatized firms used to operating in competitive markets to embrace incentive systems, structures and behavior geared to maximize efficiency and profitability, with their pre-existing exposure to a market logic, and with the partial incorporation of this logic in their operations prior to privatization (Johnson et al., 2000). Their familiarity with both logics makes it comparatively easier for them to increase emphasis on a market logic and de-emphasize a state one, making them more receptive to privatization-related changes. Their cultural repertoire already includes the resources required to operate under a market logic; they simply have to shed the structures and practices that were in place to attend to the expectations of their public owner and refocus their operations to the exclusive pursuit of business goals. In contrast, in the absence of prior exposure to market competition, public-service providers, used to operate according to a state logic, may be less receptive to the new logic they are expected to attend to after privatization.

\section{Economics systems, institutional context, and organizational change after} privatization. An institutional perspective may also help explain different change patterns in terms of the broader institutional context within which privatized companies operate. One could argue, for instance, that change in managerial practices after privatization is predicated on the availability of qualified managers, used to operate in a market environment, that can be recruited from the private sector (Al-Husan \& James, 2003; Meaney, 1995; Whitley, Henderson, Czaban, 1997) or at least on the accessibility of alternative templates for the incumbent managers (for instance, through education, training, professional advice or other structures through which managerial templates are diffused). While these conditions may be present in developed market economies, they may not be so in transitional and/or developing economies - where indeed privatization is an important step to create a market economy. This may partly explain the delayed adaptation of structure, systems, and management in privatized 
firms observed by some studies in these countries (Soulsby \& Clark, 1996; Clark \& Soulsby, 1995; Whitley \& Czaban, 1998).

As noted earlier, however, distinguishing between developed and developing (or transitional) economies comes with its limitations. A more nuanced way to describe the institutional environments of developed economies proposes to distinguish between liberal market economies (LMEs) (e.g., US, UK, Canada, Australia) and coordinated market economies (CMEs) (e.g. France, Germany, Japan, Sweden), based on the dynamics of five spheres: industrial relations, vocational training, corporate governance, inter-firm relations, and relations among employees (Hall \& Soskice, 2011) ${ }^{3}$.

These differences, we argue, may partly explain different change patterns observed by prior studies. For instance, our review highlights that studies conducted on privatization in LMEs suggest that - despite initial resistance - employees are ultimately more receptive of changes associated with privatization (Carter \& Mueller, 2002; Mackenzie, 2008). In contrast, a study of the privatization of France Telecom - a company operating in a CME - showed how changes associated with privatization resulted in continued resistance, and that "the implementation of a profit-oriented financialization strategy" led to an "unforgiving environment", which resulted in 69 employee suicides, with many of them leaving notes "blaming management for having privileged interests of shareholders over those of employees" (Chabrak, Craig, \& Daidj, 2016).

A potential explanation for these differences could be found, in particular, in the spheres of industrial relations and vocational training. The combination of trade union strength and low transferability of skills, in particular, could explain stronger resistance to privatization in CMEs. While, in LMEs, trade unions may be weakened by business and deregulation initiatives, they remain very influential in CMEs, where cross-class coalitions help preserve some degree of wage coordination (Hall \& Soskice, 2001). This idea is corroborated by research showing that the strength of unions tends to increase resistance to change, particularly 
in cases of radical changes like privatization (Meyer \& Herscovitch, 2001). Moreover, in contrast to workers in LMEs, who focus on developing highly transferable skills (due to lower employment protection), workers in CMEs focus on firm- and industry-specific skills, which may increase their anxiety in the face of change that may threaten their job security.

\section{MODERATORS: FACTORS THAT INFLUENCE PRIVATIZATION OUTCOMES}

Studies that have examined explicitly conditions that may explain different privatization outcomes point in particular to two factors: the quality of institutions and the post-privatization ownership structure (that is who the new owners are and how much capital they control).

\section{Institutional quality}

With mass-privatization programs in emerging/transitional economies not producing the outcomes that were originally promised, several scholars explored the moderating role that the quality of the institutional environment, in terms of governance mechanisms and political influence on business, has on the functioning and performance of organizations.

Governance Mechanisms. Dharwadkar, George and Brandes (2000) theorized that weak internal or external governance mechanisms - which are common in emerging economies - make traditional solutions to agency problems less effective, because they enable majority owners to disregard the interest of minorities. Under these conditions, concentration of ownership in the hands of managers may enable them to pursue their own personal interests to the detriment of profitability. Only dominant external owners, such as institutional investors or foreign multinationals, may enforce effective control systems that mitigate agency problems.

Peng, Buck, and Filatotchev (2003) similarly found that governance mechanisms such as outside directorship and the replacement of inefficient managers may be less effective than expected in driving post-privatization performance, as their effectiveness may be blunted by particular characteristics of the institutional environment. In particular, they observe that, in Russia, significant barriers to share transfers made minority shareholders represented on the 
board unable to push large scale restructuring and overcome the reluctance of managers - even those recruited post privatization - characterized by a collectivist mentality.

Political Influence. Although early work on privatization (Yarrow, 1986) argued that the process would lead to "depoliticization", much empirical research suggests otherwise, as the maintenance of close relationships between privatized firms' managers and politicians seems to be a global phenomenon, across sectors and privatization methods (Boubakri, Cosset, \& Safar, 2008; Fan, Wong, \& Zhang, 2007; Parker \& Sall, 2003). It is not uncommon, research shows, that politicians and government bureaucrats continue to influence the governance of privatized firms, even after privatization, either through formal (state regulation) or informal channels (personal ties with managers).

This phenomenon has been shown to have a negative effect on the performance of former SOEs. Boubakri and colleagues (2008), for instance have shown that the presence of politicians in the board of privatized firms seems to negatively affect financial performance, possibly because these directors use their position to press managers towards the continued pursuit of political goals (Boubakri et al., 2008). Similarly, Fan, Wong and Zhang (2007) found that newly privatized Chinese firms with politically connected CEOs underperformed those without politically connected CEOs by almost $18 \%$ (based on 3-year post-IPO returns); they explained this result with the tendency of politically connected CEOs to appoint other bureaucrats to key managerial positions, rather than managers with relevant professional experience.

\section{Post-privatization ownership structure}

Earlier, we observed that apparent discrepancies among the observed outcome of privatization around the world - or even in the same country - can be partly explained by the method used to divest. Privatizations, however, also differ in the degree to which capital is transferred to private investors (ranging from partial to full privatization) (Ramamurti, 2000), 
and in the type of investors that buy equity and acquire control (Dharwadkar et al., 2000). Some studies examined how these differences influence the outcomes of privatization.

Degree of privatization. A study of privatizations in 59 countries between 1977 and 1997 revealed that only $11.5 \%$ of the firms were fully privatized; less than $30 \%$ sold more than half through IPO (Jones et al.,1999). Later studies shown how the majority of privatization processes around the world continues to be partial, leaving the government with a minority or majority stake (Gupta, 2005; Boubakri et al., 2008; Fan et al., 2007). Only a small number of studies on the impact of privatization on performance, however, acknowledged this distinction (Megginson \& Sutter, 2006). Those that did, found mixed support for the theoretical prediction that fully privatized enterprises would outperform partially state-owned ones (Megginson, 2005; Shleifer \& Vishny, 1994).

Partial privatization, some scholars argued, may lead to improve monitoring, but, to the extent that a firm remains under government control, managers may still be subject to political interference. Other scholars warned that combining partial privatization with full managerial control may cause serious governance problems whereby, in the absence of effective oversight, private investors may manage the enterprise to maximize their own benefits, for instance, through skimming the top line rather than the bottom line (Munir \& Naqvi, 2017).

Megginson's (2005) observation that, within the banking sector, fully privatized enterprises outperform partially privatized ones offered initial support this idea. Later studies, using large samples across multiple countries and industries, corroborated the assumption that privatized firms with high residual state ownership would exhibit lower financial performance (Boubakri, Cosset \& Guedhami, 2009; Boubakri, Guedhami, Kwok, \& Saffar, 2016). Greve and Man Zhang (2017) also showed how partially privatized firms (listed on the stock exchange but not entirely independent from the State) are less likely to engage in market-oriented M\&As, making them less likely to maximize their financial returns. 
Other studies, however, revealed a positive influence of residual state ownership on financial performance (Vaaler \& Schrage, 2009). Researchers explain these observations through the fact that in industries associated with large-scale infrastructural projects, partial state ownership can help reduce risk (Doh, Teegen \& Mudambi, 2004) and signal political support for managerial initiatives (Vaaler \& Schrage, 2009). Also, large-scale studies on the impact of partial privatization acknowledge that while, on average, full privatization tends to be associated with higher performance, the presence of "sound institutional and political environments" - in the form of strong rule of law and low corruption in the political system seems to mitigate the negative impact of residual state ownership (Boubakri et al., 2009, p.368).

Type of owners. Some scholars also explored the moderating effects of the type of investors that acquire ownership and control of newly privatized firms. By studying Chinese privatizations, Wang and Judge (2012), for instance, showed that managerial ownership (i.e. percentage of shares owned by managers) tends to improve performance more than openly selling shares on the stock exchange. They argue that in economies transitioning from centralized planning to market control, internal incentives to managers may be more effective than external market mechanisms. Internal incentives, however, seem to be effective only at the managerial level, as D'Souza, Megginson, and Nash (2001) found that partially privatized firms with lower employee ownership and a higher state ownership (or a higher degree of foreign ownership) tend to display comparatively stronger profitability gains.

Boubakri, Cosset, and Guedhami (2005) tracked post-privatization ownership structure and its determinants across 32 countries, which they describe as developing, and found that the positive effect of ownership concentration on firm performance matters more in countries that have weak investor protection, and that - contrary to other studies - ownership by domestic investors tends to be associated with higher performance. In contrast, other studies (e.g. Estrin et al., 2009; Uhlenbruck \& Castro, 2000) have shown a more positive effect of foreign investors 
on firm performance; this was typically the case of firms in transitioning economies acquired by large foreign multinationals and integrated into their international system of operations.

Institutional context and the impact of residual state ownership on performance. Research on economic systems may help us shed further light on how the institutional context may shape decisions about retaining residual shareholding in privatized firms, and their implications, with a particular focus on what scholars initially labelled as "developing" and/or "transitional" economies. While acknowledging the usefulness of the framework presented earlier (Hall \& Soskice, 2001) to differentiate countries in the Western hemisphere, scholars have criticised this classification for failing to appreciate the variety of configurations in what were previously labelled as developing economies. To address this issue, Fainshmidt and colleagues (2018) proposed a typology comprising seven distinct, empirically derived national institutional systems (Fainshmidt et al., 2018).

An application of this framework, for instance, can help explain divergence in the performance outcomes of privatization in what Fainshmidt and colleagues refer to as "collaborative agglomerations" and "state-led configuration" by highlighting the differential impact of residual state ownership in the two systems. Collaborative agglomerations is a label used to group eight economies within Eastern Europe (e.g. Czech Republic, Estonia, Hungary), who, after transitioning to a free market economy, developed economic systems where the state plays a developmental role by investing into industrial sectors, ownership is not highly concentrated but must coordinate with labour nevertheless; although they can be considered still emerging, they share many characteristics with traditional CME's (e.g. Germany), while being more focused on growth than on welfare programs (Fainshmidt et al., 2018). The notion of state-led configuration, conversely, includes 15 countries (e.g. Russia, China, India) that share similarities despite having different political regimes. In these countries, the state takes an active and direct role in the economic ordering of society, and political networks are a key 
mechanism through which economic activities are conducted. Although family ownership is present, the dominant role of the state implies that these families are closely tied to the state.

Although evidence from collaborative agglomerations has shown that fully privatized enterprises tend to outperform partially privatized ones, studies from countries that operate within state-led configurations seem to show more mixed results (Estrin \& Pelletier, 2018). This could be explained by the different role that the state plays in the economy in the two types of countries. Within state-led configurations, the state tends to keep a share of ownership in the best performing enterprises (Fainshmidt et al., 2018) and to intervene in the economy by favouring certain enterprises (e.g. awarding projects, financing, adapting regulation etc.) over others. In these configurations, therefore, partial state-ownership may not necessarily hamper performance, as performance enhancements arising from political advantages may well outweigh the performance decrease associated with political interference.

\section{TAKING STOCK AND MOVING FORWARD: IMPLICATIONS FOR FUTURE}

\section{RESEARCH}

Our review of the vast literature on privatization challenges some long-standing assumptions about the implications of a shift from public to private ownership and offers a more nuanced and contextualized understanding of this widespread phenomenon (see Table 1 for a summary of our results). The decision to privatize seems to be driven more often by budgetary needs than a genuine desire to improve the efficiency of state-run services. In particular, considerable variation can be observed, across countries as well as industries, in the impact of privatization on the governance, structure, systems, strategy, culture, and performance of SOEs. All of this questions the assumption that transfer of ownership to private investors, per se, will lead to organizational change, improved financial performance, service quality, innovation output, and international expansion. These conclusions are in line with a 
review of recent studies in finance (Megginson, 2017) ${ }^{4}$ and a meta-analysis of research on postprivatization performance (Bachiller, 2017).

---Insert Table 1. About here---

In fact, as Table 1 shows, past studies produced mixed results and whether privatization will actually deliver these results seem to largely depend on the presence of factors such as competitive pressures (e.g., Bortolotti et al., 2002; Cubbin \& Stern, 2006), well-functioning incentive systems (Whitley \& Czaban, 1998, Rodriguez et al., 2007), governance mechanisms (e.g., Peng, Buck, Filatotchev, 2003; Uhlenbruck \& Castro, 2000) and regulatory frameworks (e.g., Zhang, et al., 2008; Ogden \& Watson, 1999), and the availability of managerial expertise (Soulsby \& Clark, 1996). In the absence of these conditions, instead, privatization may fail to address bureaucracy and inertia, or simply transfer lucrative economic activities to private investors with no appreciable improvement for the public (Munir \& Naqvi, 2017).

These observations highlight the importance of a contextualized understanding of privatization - one that acknowledges the influence of various factors at organizational, industry, and societal level on the outcome of privatization. In this section, we outline some avenues for future research that build on insights produced by our review.

\section{Taking a Holistic View of Privatization}

Past research has rarely examined antecedents and outcomes of privatization simultaneously. Therefore, while we know that different factors may weigh in on the decision to privatize, and that this decision may impact a range of outcomes, we know less about how the motives driving the decision influence the outcome of the process.

Our review clearly shows that not all privatizations are necessarily motivated by the desire to make SOEs more efficient - as typical micro-economic arguments would seem to suggest (Milhaupt \& Pargendler, 2017; Vickers \& Yarrow, 1991). Indeed, some privatizations are driven by a need to pay off foreign or domestic debt (Ramamurti, 1992), while others are 
motivated by political expediency, or the desire to enrich cronies who can then add to the coffers of the ruling party's fund for the next election. This is particularly the case in developing countries, where an ideological bias is often also evident in such transactions (Munir \& Naqvi, 2017). In such cases, goal posts can be moved post-privatization to claim success. For example, higher post-privatization profitability can be attributed to the transaction's 'success' even when it is clearly due to a highly favourable regulatory regime instituted particularly for this purpose.

Our review should encourage future researchers to take a holistic view of privatization transactions. Rather than simply assessing the consequences of privatizations, it would be advisable to look at the motivations, the justifications for privatizing particular organizations, and the goals that are set at the time. Then these can be compared to actual outcomes postprivatization. Such a perspective would take into account the dynamic nature of such transactions, where concessions are made as the transaction proceeds or unravels. This is critical since, almost by definition, privatizations tend to be intensely political affairs.

How do governments' motives to privatize affect the process and its outcome? How do the different concessions and/or contractual agreements associated with the sale influence the performance of newly privatized firms? How do changes in regulatory regime shape the success and failure of privatizations? These are only some of the possible research avenues that future scholars taking a more holistic view can explore. Addressing such questions is likely to shed new light on this important phenomenon, and indeed, results in studies that are more comprehensive and balanced

\section{Temporal Lag and the Assessment of Privatization Outcomes}

When examining the outcomes of privatization, in order to isolate the impact of ownership change from other effects, most studies tend to explore organizational implications, such as performance, innovation, or employment, shortly after privatization (Megginson \& Netter, 2001). Research on performance outcomes, for instance, generally compared performance 2 to 
3 years before and 2 to 3 years after privatization (e.g. Estrin et al., 2009; Megginson \& Netter, 2001; Munir \& Naqvi, 2017). Similarly, studies exploring the mediating processes of privatization generally focused on events occurring either during or shortly ( 2 to 4 years) after the privatization has occurred (Soulsby \& Clark, 1996; Whitley \& Czaban, 1998).

Despite the methodological benefits of such an approach, studies have shown that the implications of privatization tend not to manifest themselves immediately. Instead, they often become apparent over a longer period of time. For instance, studies exploring the impact of privatization on innovation have shown that a shift to private ownership may not have an immediate impact on $R \& D$ performance, but this performance will increase over a long period of time (Munari \& Oriani, 2005). Similarly, studies exploring the mediating processes have revealed that despite initial resistance, organizational members frequently become more receptive of internal changes induced by privatization over a longer period of time (e.g. Mackenzie, 2008; Ross, 2008). Examining the implications of privatization with different temporal lags may importantly affect the conclusions we draw from these results.

Do different outcomes of privatization manifest with different temporal lags? Is there an optimal timing and pace for the implementation of change after (or possibly before) privatization? Future research should pay more attention to long-term organizational implications of privatization, differentiate between the short-term and long-term effects (and adjust the temporal window of observation accordingly), and begin to examine in more depth temporal aspects of the pre- and post-privatization process.

\section{Privatization and Organizational Change Processes}

Several past studies have investigated changes - in systems, structure, culture and strategy resulting from privatization. With a few exceptions these studies have been largely static in nature - that is comparing snapshots of organizational features before and after privatization (e.g. Cragg \& Dyck, 2003; Soulsby \& Clark, 1995) - and/or reflecting a relatively narrow 
theoretical perspective, as they aimed at corroborating or rejecting predictions from microeconomic theories (e.g. Erakovic \& Wilson, 2005; Rodriguez et al., 2007). There appears to be a tremendous need for more processual accounts of these changes.

Van de Ven and Poole's (1995) widely used framework to organize change-process theories into four types - teleological, dialectic, life cycle, and evolutionary - may offer an excellent starting point. The vast majority of research on change after privatization seems to assume an implicit "teleological" model. Teleological models portray change as being driven by purposeful decisions aimed at pursuing well defined goals - which in the case of privatization highlights changes in incentive systems, organizational structure, managerial positions, etc. aimed at increasing efficiency of profitability. Adopting this perspective leads to a view of the privatization process primarily as sequence of steps motivated by the pursuit of a new set of goals. This pursuit is resisted by endogenous and exogenous forces that often prevent or delay the ultimate achievement of these goals.

Exploring other perspectives on change may help illuminate other important, but less studied aspects of the process. How does the interaction among different actors (political authorities, executives, trade unions, local communities, etc.) involved in the privatization process shape its outcome? Dialectic theories of change posit that change results from a synthesis of conflicting forces (Van de Ven \& Poole, 1995). Rather than assuming that change efforts will overcome resistance, or vice versa, a dialectical perspective highlights alternate arrangement that are produced as opposing forces negotiate, compromise or discover opportunities for mutual enrichment. Adopting such a perspective on change may help scholars shed new light, for instance, on how newly privatized enterprises with residual state ownership manage to reconcile the co-existence of different imperatives (or "logics"). Likewise, they can shed light on how old and new interest groups shape the redesign and functioning of governance mechanisms and organizational systems in former state-owned firms. 
In contrast, Van de Ven and Poole's (1995) third type, life-cycle theories, reveals how, in some cases, change occurs as a typical sequence of stages, and they highlight the mechanisms driving progression from one stage to the next (Van de Ven \& Poole, 1995). Can we conceive of privatization as a multi-stage process? Do different types of SOEs go through different paths as they are privatized? Johnson and colleagues (Johnson et al., 2000) offer a rare example of the application of a life-cycle perspective to privatization, as they highlight an intermediate stage where both private and public templates co-exist, before the organization finally transitions to operating like a private entity. Future research may build on this idea and examine, for instance, whether SOEs operating in different types of industries or institutional contexts experience different stages after privatization or investigate the conditions that facilitate or delay progression through these stages.

\section{The Moderating Role of Owner Identity}

Our review highlights that the general assumption that a shift to private ownership per se leads to better performance may be overly simplistic, and that reality is more nuanced. This view, for instance, fails to acknowledge that not all private owners are equally equipped to reform SOEs. This is particularly important when SOEs are sold to the highest bidder. What type of private owners may be best positioned to restructure a former SOEs, timely and effectively, for higher efficiency (possibly without compromising on other aspects, such as service quality or access)? Few studies have examined the influence of the specific characteristics of the acquirer on the outcome of privatization. Those who did focused on the concentration of ownership after privatization - a relatively easy characteristic to measure. Results in this regard, however, seem to be mixed, primarily because of a second, related point: the modality of privatization can be a huge moderator when it comes to outcomes. While floating a company on the stock market - effectively entrusting it in the hands of a multitude of shareholders - generally seems 
to be more beneficial than direct sale to a single one (Bachiller, 2017), some studies have found a direct correlation between ownership concentration and performance (Boubakri et al., 2005).

While ownership concentration determines the power of owners to enforce goals, owner identity determines the preferences and goals of owners (Pedersen \& Thomsen, 2003). For instance, the performance and functioning of a privatized firm is likely to differ if the new owner is an 'oligarch' (Guriev \& Rachinsky, 2005) or a foreign multinational corporation (Rondinelli \& Black, 2000) answerable to shareholders and with a reputation at stake. Financial institutions (e.g. banks, pension funds, investment companies etc.) are another case in point. They are usually considered as portfolio investors whose main objective is shareholder wealth maximization. However, their preferences might differ depending on the state's oversight of their core business, or the involvement of various actors in it. While banks might be in favour of post-privatization downsizing in order to improve efficiency and maximize their returns, pension funds are often linked to governments and trade unions, which makes them more sensitive to political concerns like employment levels and job security (Woidtke, 2002).

These studies generally suggest that owners differ in terms of knowledge, goals, wealth constraints or political interests, and that such difference are likely to influence the way in which they exercise their right as owners, with important consequences for post-privatization behaviour and performance (Estrin et al., 2009; Pedersen \& Thomsen, 2003). Future research, therefore, should pay more attention not only to the concentration of ownership, but also to the identity and associated characteristics of relevant owners, asking questions such as How do different types of owners shape the transformation of privatized organizations? How do their own goals, competence, resources influence the direction and pace of change after privatization? 


\section{Privatization: An Institutional Perspective}

The privatization process has a number of aspects that an institutionalist approach may help shed more light on. Neo-institutional theorists are concerned with finding out how new norms are established, different meanings created, and various practices accorded legitimacy (Kostova, Roth, \& Dacin, 2008). Institutional theory illuminates how regulation is not the only force determining an organization's actions. Apart from regulation, norms and cognitive understandings provide equally powerful and perhaps more deeply entrenched devices to influence organizational dynamics (Scott, 1995). These forces, institutional theorists point out, promote converging behaviour among organizations in an industry (DiMaggio \& Powell, 1983). Isomorphic pressures, however, are not all powerful, and some divergence will likely remain in the strategies that competitors adopt, and/or in how they organize internal resources. Our review indicates that some of these differences can be explained in terms private vs. public ownership (e.g. Greve \& Man Zhang, 2017; Johnson et al., 2000). An interesting question, therefore, becomes do isomorphic pressures affect state-owned vs. privately owned firms differently? One could argue, for instance, that because of political backing and the deep pockets of the state, state-owned firms may be better positioned to resist coercive isomorphic pressures. Political constraints and social obligations may prevent state-owned enterprises from imitating efficient practices of industry leaders. By viewing themselves as fundamentally different, they may also be less prone to imitate private competitors. In fact, their public ownership may locate them at the intersection of different fields, and subject them to different, countervailing isomorphic pressures. These, however, are just speculations. More empirical work is needed to improve our understanding of whether and how privatization affects how firms respond to isomorphic pressures.

Institutionalism represents a powerful lens to understand both the effect of the institutional environment on the process and outcome of a privatization and the internal turmoil that 
organizations may experience post-privatization. How do members negotiate the cultural shift from a public sector to a private sector logic? How do privatized public service providers manage internal tensions between their historical imperative to provide a public service, and the new economic imperative to deliver profit? How do informal institutions - such as societallevel cultural norms and assumptions about appropriate organizational goals and practices influence post-privatization changes? Adopting an institutional lens may help us illuminate how privatizations can be motivated and justified in ideological terms (Kentikelenis \& Babb, 2019), and how different imperatives, e.g., public interest vs. shareholder wealth maximization, can collide in recently privatized organizations (Johnson et al., 2000).

\section{Privatization, Resilience and Crisis Response}

Our review shows how past research on the outcomes of privatization has overwhelmingly concentrated on financial and operating performance, reflecting a focus on the impact of this transition on the firms themselves rather their broader constituents. Possibly resting on the neoclassical economics assumption that the pursuit of the interest of private firms (or, rather, their shareholders) will be beneficial for society at large, these studies have sidestepped broader considerations, such as public interest, when focusing on the efficiency or profitability of these firms (Jupe \& Funnell, 2015; Kentikelenis \& Babb, 2019; Munir \& Naqvi, 2017).

This is not to question the importance of the long-term economic viability of a firm - be it state-owned or privately owned. Privatization programs around the world, however, have often transferred to private investors firms and/or assets involved in the production and delivery of services considered of public utility (Barley, 2007; Miranda \& Lerner, 1995). This transfer has often occurred in the absence of viable market structures or regulatory oversight that would ensure effective delivery or affordable access, and prevent private operators from designing their operations - be it the type of services they offer, the modalities of their delivery, or the 
cost at the which are delivered - to maximize their own interest rather that the interest of the constituents they are expected to serve (Roland, 2008; Kentikelenis \& Babb, 2019).

The Covid-19 pandemic has thrown the implications of these situations into stark relief. In the United Kingdom, entrusting private firms with the stockpiling of emergency medical equipment resulted in poor inventory management and delayed delivery (Lawrence, Garside, Pegg, Conn, Carrell, \& Davies, 2020), and the outsourcing of the Covid-19 helpline to private contractors has been blamed for inadequate assistance and unnecessary deaths (Conn, 2020). In the Italian region of Lombardy, ample reliance on private health care resulted in a shortage of intensive care units and testing labs (Munster, 2020). Political choices justified by expected cost savings or quality improvements revealed their inadequacy to handle emergencies, as public structures had to step in to compensate for private operations designed primarily to benefit from the lucrative opportunities that they had been afforded.

The Covid-19 pandemic, we argue, should encourage scholars to revisit the implications of privatization - broadly understood - setting aside the widely studied issue of whether and how privatization improves efficiency, to examine instead the consequences of privatization on the overall resilience of a system in face of crises. How do public vs. private service providers respond to systemic emergencies that require to temporarily sacrifice profitability to the common good? Under what conditions can privatized services be brought back under state control? What are the implications of privatizing services that are intended to be activated only in case of emergency? What are the challenges (and opportunities) that private and public providers encounter as they try to collaborate to address a collective emergency? The Covid19 pandemic, in this respect, offers an extraordinary opportunity for comparative research on the implications of different choices - within and across countries - about the allocation of responsibility for the delivery of critical services - such as health care, social care, or emergency response - to different combinations of public vs. private entities. 


\section{CONCLUSION}

As mentioned above, the Covid-19 pandemic has put privatization back in the public eye. Support for a resilient and robust public sector seems to have risen, just as questions about the primacy of shareholder wealth maximization above everything else - declining employment or employee help in times of distress - have started to be asked. A new consensus around a more balanced and stable economy seems to be forming. At a time like this, it is crucially important to take stock of what we know about privatization.

Our review provides a foundation upon which a new body of work on privatization can build. In particular, our review has highlighted the importance of taking into account the institutional environment in which privatization takes place. This not only allows us to bring in regulatory regimes, political influence and corruption into the picture but also encourages us to focus on how different institutional logics come together inside the enterprise.

Privatization can be a powerful device for increasing the competitiveness of economies. At the same time, if pursued for ideological or political reasons, it can lead to rent-seeking and general decrease in economic competitiveness of a country. If we do not take a balanced perspective, we can end up in a situation where profits are privatised while losses are socialized. We hope that our extensive review of research around this topic will allow for more informed research and practice.

\section{REFERENCES}

Aggarwal, R., Leal, R., \& Hernandez, L. 1993. The aftermarket performance of initial public offerings in Latin America. Financial Management, 22: 42-53.

Aguilera, R. V., \& Grøgaard, B. 2019. The dubious role of institutions in international business: A road forward. Journal of International Business Studies, 50: 20-35.

Al-Husan, F. B., \& James, P. 2003. Cultural control and multinationals: the case of privatized Jordanian companies. International Journal of Human Resource Management, 14: 12841295.

Al-Jazzaf, M. I. 1999. Impact of privatization on airlines performance: an empirical analysis. Journal of Air Transport Management, 5: 45-52.

Alexandre, H., \& Charreaux, G. 2004. Efficiency of French privatizations: a dynamic vision. Journal of Corporate Finance, 10: 467-494.

Alford, J. 1993. Towards a New Public Management Model: Beyond "Managerialism" and Its Critics. Australian Journal of Public Administration, 52: 135-148. 
Alonso, J. M., Clifton, J., Díaz-Fuentes, D., Fernández-Gutiérrez, M., \& Revuelta, J. 2013. The race for international markets: were privatized telecommunications incumbents more successful than their public counterparts? International Review of Applied Economics, 27: 215-236.

Arcas, M. J., \& Bachiller, P. 2010. Operating performance of privatized firms in Europe: organizational and environmental factors. International Journal of Public Administration, 33: 487-498.

Azam, J. P., Biais, B., \& Dia, M. 2004. Privatisation versus regulation in developing economies: the case of West African banks. Journal of African Economies, 13, 361-394.

Bachiller, P. 2017. A meta-analysis of the impact of privatization on firm performance. Management Decision, 55: 178-202.

Balza, L., Jimenez, R., \& Mercado, J. 2013. Privatization, institutional reform, and performance in the Latin American electricity sector. Inter-American Development Bank, Infrastructure and Environment Department, Energy Division, Technical Note No. IDBTN-599.

Barley, S. R. 2007. Corporations, democracy, and the public good. Journal of Management Inquiry, 16: 201-215.

Belloc, F. 2014. Innovation in state-owned enterprises: reconsidering the conventional wisdom. Journal of Economic Issues, 48: 821-848.

Bennett, J., Estrin, S., \& Urga, G. 2007. Methods of privatization and economic growth in transition economies. Economics of Transition, 15: 661-683.

Bennett, J., Estrin, S., Maw, J., \& Urga, G. 2003. The Impact of Different Privatization Methods on Growth in Transition Economies. Centre for New and Emerging Markets Discussion Paper, 30.

Berger, A. N., Clarke, G. R., Cull, R., Klapper, L., \& Udell, G. F. 2005. Corporate governance and bank performance: A joint analysis of the static, selection, and dynamic effects of domestic, foreign, and state ownership. World Bank Policy Research Working Paper

Berne, M., \& Pogorel, G. 2006. Privatization experiences in France. In M. Kothenburger, H.W. Sinn, \& J. Whalley (Eds) Privatization Experiences in the European Union, 163-198. Cambridge, MA: MIT University Press.

Bhaskar, V., \& Khan, M. 1995. Privatization and employment: A study of the jute industry in Bangladesh. American Economic Review, 85: 267-273.

Biais, B., \& Perotti, E. 2002. Machiavellian privatization. American Economic Review, 92: 240-258.

Biglaiser, G., \& Brown, D. S. 2003. The determinants of privatization in Latin America. Political Research Quarterly, 56: 77-89.

Boardman, A. E., \& Vining, A. R. 1989. Ownership and performance in competitive environments: A comparison of the performance of private, mixed, and state-owned enterprises. Journal of Law and Economics, 32: 1-33.

Bognetti, G., \& Obermann, G. 2008. Liberalization and privatization of public utilities: origins of the debate, current issues and challenges for the future. Annals of Public and Cooperative Economics, 79: 461-485.

Bonin, J. P., Hasan, I., \& Wachtel, P. 2005. Bank performance, efficiency and ownership in transition countries. Journal of Banking \& Finance, 29: 31-53.

Bortolotti, B., D'Souza, J., Fantini, M., \& Megginson, W. L. 2002. Privatization and the sources of performance improvement in the global telecommunications industry. Telecommunications Policy, 26: 243-268.

Bortolotti, B., Fantini, M., \& Siniscalco, D. 1998. Regulation and privatisation: The case of electricity. 70. Nota di Lavoro. 
Boubakri, N., \& Cosset, J. C. 1998. The financial and operating performance of newly privatized firms: Evidence from developing countries. Journal of Finance, 53:1081-1110.

Boubakri, N., Cosset, J. C., \& Guedhami, O. 2005. Post privatization corporate governance: The role of ownership structure and investor protection. Journal of Financial economics, 76: 369-399.

Boubakri, N., Cosset, J. C., \& Guedhami, O. 2009. From state to private ownership: Issues from strategic industries. Journal of Banking \& Finance, 33: 367-379.

Boubakri, N., Cosset, J. C., \& Saffar, W. 2008. Political connections of newly privatized firms. Journal of Corporate Finance, 14: 654-673.

Boubakri, N., Cosset, J. C., Fischer, K., \& Guedhami, O. 2005. Privatization and bank performance in developing countries. Journal of Banking \& Finance, 29: 2015-2041.

Boubakri, N., Guedhami, O., Kwok, C. C., \& Saffar, W. 2016. National culture and privatization: The relationship between collectivism and residual state ownership. Journal of International Business Studies, 47: 170-190.

Boycko, M., Shleifer, A., \& Vishny, R. W. 1994. Voucher privatization. Journal of Financial Economics, 35: 249-266.

Boycko, M., Shleifer, A., \& Vishny, R. W. 1996. A theory of privatisation. The Economic Journal, 106: 309-319.

Bozec, R., Dia, M. \& Breton, G. 2006. Ownership-efficiency relationship and the measurement selection bias, Accounting and Finance, 46: 733-754.

Breen, M., \& Doyle, D. 2013. The determinants of privatization: A comparative analysis of developing countries. Journal of Comparative Policy Analysis: Research and Practice, 15: $1-20$.

Bruton, G. D., Ahlstrom, D., \& Li, H. L. 2010. Institutional theory and entrepreneurship: where are we now and where do we need to move in the future? Entrepreneurship Theory and Practice, 34: 421-440.

Bruton, G. D., Peng, M. W., Ahlstrom, D., Stan, C., \& Xu, K. 2015. State-owned enterprises around the world as hybrid organizations. Academy of Management Perspectives, 29: 92114.

Carney, M., Estrin, S., Liang, Z., \& Shapiro, D. 2019. National institutional systems, foreign ownership and firm performance: The case of understudied countries. Journal of World Business, 54:244-257.

Carter, C., \& Mueller, F. 2002. The 'long march 'of the management modernizers: Ritual, rhetoric and rationality. Human Relations, 55: 1325-1354.

Chabrak, N., Craig, R., \& Daidj, N. 2016. Financialization and the employee suicide crisis at France Telecom. Journal of Business Ethics, 139: 501-515.

Claessens, S., \& Djankov, S. 1999. Ownership concentration and corporate performance in the Czech Republic. Journal of Comparative Economics, 27: 498-513.

Claessens, S., \& Djankov, S. 2002. Privatization benefits in Eastern Europe. Journal of Public Economics, 83: 307-324.

Claessens, S., Djankov, S., \& Pohl, G. 1997. Ownership and corporate governance: Evidence from the Czech Republic, World Bank Publications, 1737.

Clark, E., \& Soulsby, A. 1995. Transforming former state enterprises in the Czech Republic. Organization Studies, 16: 215-242.

Clark, E., \& Soulsby, A. 1998. Organization-community embeddedness: The social impact of enterprise restructuring in the post-communist Czech Republic. Human Relations, 51: 2550.

Clark, E., \& Soulsby, A. 1999. The Adoption of the Multi-divisional Form in Large Czech Enterprises: The Role of Economic, Institutional and Strategic Factors. Journal of Management Studies, 36: 535-559. 
Clark, E., \& Soulsby, A. 2007. Understanding top management and organizational change through demographic and processual analysis. Journal of Management Studies, 44: 932954.

Clifton, J., Díaz-Fuentes, D., \& Revuelta, J. 2010. The political economy of telecoms and electricity internationalization in the single market. Journal of European Public Policy, 17: 988-1006.

Conn, D., 2020. 'I'm traumatised now': Covid bereaved call for inquiry into NHS 111. The Guardian, Retrieved from: https:/www.theguardian.com/world/2020/sep/21/covidbereaved-call-for-inquiry-into-nhs-111-handling-of-crisis

Cragg, M. I., \& Dyck, I. A. 2003. Privatization and management incentives: Evidence from the United Kingdom. Journal of Law, Economics, and Organization, 19: 176-217.

Crockford, D. 1994. Strategic management in privatized businesses. Long Range Planning, 27: 111-118.

Cubbin, J., \& Stern, J. 2006. The impact of regulatory governance and privatization on electricity industry generation capacity in developing economies. World Bank Economic Review, 20: 115-141.

Cuervo, A., \& Villalonga, B. 2000. Explaining the variance in the performance effects of privatization. Academy of Management Review, 25: 581-590.

Cunha, R. C., \& Cooper, C. L. 2002. Does privatization affect corporate culture and employee wellbeing? Journal of Managerial Psychology, 17: 21-49.

Czaban, L., \& Whitley, R. 2000. Incremental organizational change in a transforming society: Managing turbulence in Hungary in the 1990s. Journal of Management Studies, 37: 371393.

D’Souza, J., \& Megginson, W. L. 1999. The financial and operating performance of privatized firms during the 1990s. The Journal of Finance, 54: 1397-1438.

D’Souza, J., Megginson, W., \& Nash, R. 2001. Determinants of performance improvements in privatized firms: the role of restructuring and corporate governance. Working Paper, University of Oklahoma, Norman.

D'Souza, J., Megginson, W., \& Nash, R. 2005. Effect of institutional and firm-specific characteristics on post-privatization performance: Evidence from developed countries. Journal of Corporate Finance, 11: 747-766.

Dean, A., Carlisle, Y., \& Baden-Fuller, C. 1999. Punctuated and continuous change: the UK water industry. British Journal of Management, 10: 3-18.

Dharwadkar, B., George, G., \& Brandes, P. 2000. Privatization in emerging economies: An agency theory perspective. Academy of Management Review, 25: 650-669.

Dinc, I. S., \& Gupta, N. 2011. The decision to privatize: Finance and politics. The Journal of Finance, 66: 241-269.

Doh, J. P., Teegen, H., \& Mudambi, R. 2004. Balancing private and state ownership in emerging markets' telecommunications infrastructure: Country, industry, and firm influences. Journal of International Business Studies, 35: 233-250.

Dore, M. H., Kushner, J., \& Zumer, K. 2004. Privatization of water in the UK and FranceWhat can we learn? Utilities Policy, 12: 41-50.

Doyle, D. 2010. Politics and Privatization: Exogenous pressures, domestic incentives and state divestiture in Latin America. Journal of Public Policy, 30: 291-320.

Drucker, P. [1969] 2017. The age of discontinuity: Guidelines to our changing society. Routledge. London, UK. William Heinemann Ltd.

Dunleavy, P. 1986. Explaining the privatization boom: public choice versus radical approaches. Public Administration, 64: 13-34.

Dyck, I. A. 1997. Privatization in Eastern Germany: management selection and economic transition. American Economic Review, 87: 565-597. 
Earle, J. S., \& Estrin, S. 2003. Privatization, competition, and budget constraints: disciplining enterprises in Russia. Economics of Planning, 36: 1-22.

Eckel, C., Eckel, D., \& Singal, V. 1997. Privatization and efficiency: Industry effects of the sale of British Airways. Journal of Financial Economics, 43:275-298.

Ehrlich, I., Gallais-Hamonno, G., Liu, Z., \& Lutter, R. 1994. Productivity growth and firm ownership: An analytical and empirical investigation. Journal of Political Economy, 102: 1006-1038.

Erakovic, L., \& Wilson, M. 2005. Conditions of radical transformation in state-owned enterprises. British Journal of Management, 16: 293-313.

Estache, A., \& Rossi, M. A. 2002. How different is the efficiency of public and private water companies in Asia? World Bank Economic Review, 16: 139-148.

Estache, A., Rossi, M. A., \& Ruzzier, C. A. 2004. The case for international coordination of electricity regulation: evidence from the measurement of efficiency in South America. Journal of Regulatory Economics, 25: 271-295.

Estrin, S., \& Pelletier, A. 2018. Privatization in developing countries: what are the lessons of recent experience? The World Bank Research Observer, 33: 65-102.

Estrin, S., Hanousek, J., Kocenda, E., \& Svejnar, J. 2009. The effects of privatization and ownership in transition economies. Journal of Economic Literature, 47: 699-728.

Estrin, S., Liang, Z., Shapiro, D., \& Carney, M. 2019. State capitalism, economic systems and the performance of state-owned firms. Acta Oeconomica, 69:175-193.

Estrin, S., Meyer, K. E., Nielsen, B. B., \& Nielsen, S. 2016. Home country institutions and the internationalization of state-owned enterprises: A cross-country analysis. Journal of World Business, 51: 294-307.

Fainshmidt, S., Judge, W. Q., Aguilera, R. V., \& Smith, A. 2018. Varieties of institutional systems: A contextual taxonomy of understudied countries. Journal of World Business, 53 : 307-322.

Fan, J. P., Wong, T. J., \& Zhang, T. 2007. Politically connected CEOs, corporate governance, and Post-IPO performance of China's newly partially privatized firms. Journal of Financial Economics, 84: 330-357.

Feng, F., Sun, Q. and Tong, W.H. 2004. Do government-linked companies underperform? Journal of Banking and Finance, 28: 2461-2492.

Filatotchev, I., Buck, T., \& Zhukov, V. 2000. Downsizing in privatized firms in Russia, Ukraine, and Belarus. Academy of Management Journal, 43: 286-304.

Filatotchev, I., Wright, M., Uhlenbruck, K., Tihanyi, L., \& Hoskisson, R. E. 2003. Governance, organizational capabilities, and restructuring in transition economies. Journal of World Business, 38: 331-347.

Fink, S. 2011. A contagious concept: Explaining the spread of privatization in the telecommunications sector. Governance, 24:111-139.

Ford, J., \& Plimmer, G. 2019. Returning the UK's privatised services to the public. Financial Times. Retrieved from: https://www.ft.com/content/90c0f8e8-17fd-11e8-9e9c$\underline{25 \mathrm{c} 814761640 .}$.

Friedland, R., \& Alford, R. R. 1991. Bringing society back in: Symbols, practices, and institutional contradictions. In W. W. Powell \& P. DiMaggio (Eds.), The new institutionalism in organizational analysis: 232-263. Chicago, IL: University of Chicago Press.

Frydman, R., Gray, C., Hessel, M., \& Rapaczynski, A. 1999. When does privatization work? The impact of private ownership on corporate performance in the transition economies. The Quarterly Journal of Economics, 114: 1153-1191.

Galal, A., L. Jones, P. Tandon, and I. Vogelsang. 1994. Welfare Consequences of Selling Public Enterprises. Oxford: Oxford University Press. 
Gasmi, F., Maingard, A., Noumba, P., \& Virto, L. R. 2013. The privatization of the fixed-line telecommunications operator in OECD, Latin America, Asia, and Africa: One size does not fit all. World Development, 45: 189-208.

Goldeng, E., Grünfeld, L. A., \& Benito, G. R. 2008. The performance differential between private and state-owned enterprises: The roles of ownership, management and market structure. Journal of Management Studies, 45: 1244-1273.

Graham, B. 1997. Air transport liberalization in the European Union: an assessment. Regional Studies, 31: 807.

Greenwald, B. C., \& Stiglitz, J. E. 1986. Externalities in economies with imperfect information and incomplete markets. The Quarterly Journal of Economics, 101: 229-264.

Greve, H. R., \& Man Zhang, C. 2017. Institutional logics and power sources: Merger and acquisition decisions. Academy of Management Journal, 60: 671-694.

Grugulis, I., \& Wilkinson, A. 2002. Managing culture at British Airways: hype, hope and reality. Long Range Planning, 35: 179-194.

Guo, K., \& Yao, Y. 2005. Causes of privatization in China: Testing several hypotheses. Economics of Transition, 13: 211-238.

Gupta, N. 2005. Partial privatization and firm performance. Journal of Finance, 60: 987-1015.

Gupta, N. 2011. Selling the Family Silver to Pay the Grocer's Bill? Working Paper, Indiana University

Gupta, N., Ham, J. C., \& Svejnar, J. 2008. Priorities and sequencing in privatization: Evidence from Czech firm panel data. European Economic Review, 52: 183-208.

Guriev, S., \& Rachinsky, A. 2005. The role of oligarchs in Russian capitalism. Journal of Economic Perspectives, 19: 131-150.

Hall, P., \& Soskice, D. 2001. Varieties of capitalism: the institutional foundations of comparative advantage. Oxford: Oxford University Press.

Hammer, R. M., Hinterhuber, H. H., \& Lorentz, J. 1989. Privatization-A cure for all ills? Long Range Planning, 22: 19-28.

Harper, J. T. 2002. The performance of privatized firms in the Czech Republic. Journal of Banking \& Finance, 26: 621-649.

Harrow, J., \& Willcocks, L. 1990. Public services management: activities, initiatives and limits to learning. Journal of Management Studies, 27: 281-304.

Hart, O., Shleifer, A., \& Vishny, R. W. 1997. The proper scope of government: theory and an application to prisons. The Quarterly Journal of Economics, 112: 1127-1161.

Hartley, P. R., \& Medlock III, K. B. 2013. Changes in the operational efficiency of national oil companies. The Energy Journal, 34: 27-57,

Henig, J. R. 1989. Privatization in the United States: Theory and practice. Political Science Quarterly, 104: 649-670.

Henisz, W. J., Zelner, B. A., \& Guillén, M. F. 2005. The worldwide diffusion of marketoriented infrastructure reform, 1977-1999. American Sociological Review, 70: 871-897.

Hitt, M. A., Sirmon, D. G., Li, Y., Ghobadian, A., Arregle, J. L., \& Xu, K. 2020. Institutions, industries and entrepreneurial versus advantage-based strategies: how complex, nested environments affect strategic choice. Journal of Management and Governance, 1-42.

Hodge, G. 2000. Privatization: An international review of performance. Routledge.

Huang, L., \& Yao, Y. 2010. Impacts of privatization on employment: evidence from China. Journal of Chinese Economic and Business Studies, 8:133-156.

Huang, Z., \& Wang, K. 2011. Ultimate privatization and change in firm performance: Evidence from China. China Economic Review, 22: 121-132.

Inoue, C. F., Lazzarini, S. G., \& Musacchio, A. 2013. Leviathan as a minority shareholder: Firm-level implications of state equity purchases. Academy of Management Journal, 56: $1775-1801$. 
Johnson, G., Smith, S., \& Codling, B. 2000. Microprocesses of institutional change in the context of privatization. Academy of Management Review, 25: 572-580.

Jones, D. C. 1998. The economic effects of privatization: evidence from a Russian panel. Comparative Economic Studies, 40: 75-102.

Jones, S. L., Megginson, W. L., Nash, R. C., \& Netter, J. M. 1999. Share issue privatizations as financial means to political and economic ends. Journal of Financial Economics, 53: 217253.

Jupe, R., \& Funnell, W. 2015. Neoliberalism, consultants and the privatisation of public policy formulation: The case of Britain's rail industry. Critical Perspectives on Accounting, 29: $65-85$.

Kaufmann, D., \& Siegelbaum, P. 1997. Privatization and corruption in transition economies. Journal of International Affairs, 50: 419-458.

Kentikelenis, A. E., \& Babb, S. 2019. The making of neoliberal globalization: norm substitution and the politics of clandestine institutional change. American Journal of Sociology, 124: 1720-1762.

Kirkpatrick, C., Parker, D., \& Zhang, Y. F. 2006. An empirical analysis of state and privatesector provision of water services in Africa. The World Bank Economic Review, 20: 143163.

Koppell, J. G. 2007. Political control for China's state-owned enterprises: lessons from America's experience with hybrid organizations. Governance, 20: 255-278.

Kostova, T., Roth, K., \& Dacin, M. T. 2008. Institutional theory in the study of multinational corporations: A critique and new directions. Academy of Management Review, 33: 9941006.

La Porta, R., \& Lopez-de-Silanes, F. 1999. The benefits of privatization: Evidence from Mexico. The Quarterly Journal of Economics, 114: 1193-1242.

Laffont, J. J., \& Tirole, J. 1991. The politics of government decision-making: A theory of regulatory capture. The Quarterly Journal of Economics, 106: 1089-1127.

Lawrence, F., Garside, J., Pegg, D., Conn, D., Carrell, S. \& Davies, H., 2020. How a decade of privatisation and cuts exposed England to coronavirus. The Guardian. Retrieved from: https://www.theguardian.com/world/2020/may/31/how-a-decade-of-privatisation-andcuts-exposed-england-to-coronavirus

Li, W., \& Xu, L. C. 2004. The impact of privatization and competition in the telecommunications sector around the world. Journal of Law and Economics, 47: 395-430.

Li, X. 2011. Sources of external technology, absorptive capacity, and innovation capability in Chinese state-owned high-tech enterprises. World Development, 39: 1240-1248.

Liao, L., Liu, B., \& Wang, H. 2014. China' s secondary privatization: Perspectives from the split-share structure reform. Journal of Financial Economics, 113: 500-518.

MacKenzie, R. 2008. From networks to hierarchies: The construction of a subcontracting regime in the Irish telecommunications industry. Organization Studies, 29: 867-886.

Majumdar, S. K. 1996. "Assessing Comparative Efficiency of the State-Owned, Mixed, and Private Sectors in Indian Industry." Public Choice 96: 1-24.

Maquieira, C., \& Zurita, S. 1996. Privatization in Chile: Efficiency and Financial Policies. Administration Studies, 3: 1-36.

Martin, S., \& Parker, D. 1995. Privatization and economic performance throughout the UK business cycle. Managerial and Decision Economics, 16: 225-237.

Marwell, N. P. 2004. Privatizing the welfare state: Nonprofit community-based organizations as political actors. American Sociological Review, 69: 265-291.

Meaney, C. S. 1995. Foreign experts, capitalists, and competing agendas: privatization in Poland, the Czech Republic, and Hungary. Comparative Political Studies, 28: 275-305. 
Meckling, W. H., \& Jensen, M. C. 1976. Theory of the firm: Managerial behavior, agency costs and ownership structure. Journal of Financial Economics, 3: 305-360.

Megginson, W. L. 2005. The economics of bank privatization. Journal of Banking \& Finance, 29: 1931-1980.

Megginson, W. L. 2017. Privatization, State Capitalism, and State Ownership of Business in the $21^{\text {st }}$ Century. Foundations and Trends in Finance 11: 1-153

Megginson, W. L., \& Netter, J. M. 2001. From state to market: A survey of empirical studies on privatization. Journal of Economic Literature, 39: 321-389.

Megginson, W. L., \& Netter, J. M. 2003. History and methods of privatization. In D. Parker \& D. Saal (Eds) International Handbook on Privatization. 25-40 Northampton, MA: Edward Elgar Publishing.

Megginson, W. L., \& Sutter, N. L. 2006. Privatisation in developing countries. Corporate Governance: An International Review, 14: 234-265.

Megginson, W. L., Nash, R. C., \& Van Randenborgh, M. 1994. The financial and operating performance of newly privatized firms: An international empirical analysis. Journal of Finance, 49: 403-452.

Megginson, W. L., Nash, R. C., Netter, J. M., \& Schwartz, A. L. 2000. The long-run return to investors in share issue privatization. Financial management, 29: 67-77.

Meyer, J. P., \& Herscovitch, L. 2001. Commitment in the workplace: Toward a general model. Human Resource Management Review, 11: 299-326.

Meyer, K. E. 2002. Management challenges in privatization acquisitions in transition economies. Journal of World Business, 37: 266-276.

Milhaupt, C. J., \& Pargendler, M. 2017. Governance challenges of listed state-owned enterprises around the world: national experiences and a framework for reform. Cornell International Law Review, 50: 473.

Miranda, R., \& Lerner, A. 1995. Bureaucracy, organizational redundancy, and the privatization of public services. Public Administration Review, 55: 193-200.

Moe, R. C. 1987. Exploring the limits of privatization. Public Administration Review, 35: 453460.

Morley, W. B. 1986. The privatization of British Telecom-Its impact on management. Long Range Planning, 19: 124-129.

Munari, F., \& Oriani, R. 2005. Privatization and economic returns to R \& D investments. Industrial and Corporate Change, 14: 61-91.

Munari, F., \& Sobrero, M. 2003. Privatization's effects on R\&D investments. In M.Calderini, P.Garrone, M. Sobrero, (Ed.) Corporate Governance, Market Structure and Innovation, 6791. Cheltenham, UK: Edward Elgar.

Munari, F., Roberts, E. B., \& Sobrero, M. 2002. Privatization processes and the redefinition of corporate R\&D boundaries. Research Policy, 31: 31-53.

Munir, K., \& Naqvi, N. 2017. Privatization in the Land of Believers: The political economy of privatization in Pakistan. Modern Asian Studies, 51: 1695-1726.

Munster, B., 2020. What made Italy's wealthiest region so vulnerable to coronavirus? New Statesman.

Musacchio, A., \& Lazzarini, S. G. 2014. Reinventing state capitalism: Leviathan in business, Brazil and beyond. Cambridge, MA: Harvard University Press.

Nelson, L. D., \& Kuzes, I. Y. 1994. Evaluating the Russian voucher privatization program. Comparative Economic Studies, 36: 55-67.

Newbery, D. M., \& Pollitt, M. G. 1997. The restructuring and privatisation of Britain's CEGB — was it worth it? Journal of Industrial Economics, 45: 269-303.

OECD 2003. Privatising state-owned enterprises: an overview of policies and practices in OECD countries. 
OECD 2018. Privatisation and the Broadening of Ownership of State-Owned Enterprises.

Ogden, S. G. 1995. Transforming frameworks of accountability: the case of water privatization. Accounting, Organizations and Society, 20: 193-218.

Ogden, S., \& Watson, R. 1999. Corporate performance and stakeholder management: Balancing shareholder and customer interests in the UK privatized water industry. Academy of Management Journal, 42: 526-538.

Okten, C., \& Arin, K. P. 2006. The effects of Privatization on Efficiency: How does privatization work? World Development, 34:1537-1556.

Palcic, D., \& Reeves, E. 2011. Privatization, employee share ownership and governance: The case of EIRCOM. Annals of Public and Cooperative Economics, 82: 437-454.

Parker, D. 1995. 'Privatisation and agency status: identifying the critical factors for performance improvement'. British Journal of Management, 6: 29-43.

Parker, D., \& Saal, D. S. 2003. International Handbook on Privatization. Edward Elgar Publishing. Northampton, MA: USA

Pedersen, T., \& Thomsen, S. 2003. Ownership structure and value of the largest European firms: The importance of owner identity. Journal of Management and Governance, 7: 2755.

Pendleton, A. 2003. Does privatization create a 'new breed 'of managers? A study of the UK railway industry. Human Relations, 56: 85-111.

Peng, M. W., Bruton, G. D., Stan, C. V., \& Huang, Y. 2016. Theories of the (state-owned) firm. Asia Pacific Journal of Management, 33: 293-317.

Peng, M. W., Buck, T., \& Filatotchev, I. 2003. Do outside directors and new managers help improve firm performance? An exploratory study in Russian privatization. Journal of World Business, 38: 348-360.

Pollitt, M. 2008. The arguments for and against ownership unbundling of energy transmission networks. Energy policy, 36: 704-713.

Pombo, C., \& Ramirez-Gomez, M. 2005. Privatization in Colombia: A plant performance analysis. In P. Chong \& F. Lopez (Eds) Privatization in Latin America: Myths and Reality. Stanford, CA: Stanford University Press.

Ramamurti, R. 1992. Why are developing countries privatizing? Journal of International Business Studies, 23: 225-249.

Ramamurti, R. 1997. Testing the limits of privatization: Argentine railroads. World Development, 25: 1973-1993.

Ramamurti, R. 2000. A multilevel model of privatization in emerging economies. Academy of Management Review, 25: 525-550.

Ring, P. S., \& Perry, J. L. 1985. Strategic management in public and private organizations: Implications of distinctive contexts and constraints. Academy of Management Review, 10: 276-286.

Rodríguez, G. C., Espejo, C. A. D., \& Cabrera, R. V. 2007. Incentives management during privatization: An agency perspective. Journal of Management Studies, 44: 536-560.

Roland, G. 2008. Privatization: Success and Failures. New York: Columbia University Press.

Roland, G., \& Sekkat, K. 2000. Managerial career concerns, privatization and restructuring in transition economies. European Economic Review, 44: 1857-1872.

Rondinelli, D. A., \& Black, S. S. 2000. Multinational strategic alliances and acquisitions in Central and Eastern Europe: Partnerships in privatization. Academy of Management Perspectives, 14: 85-98.

Ross, P. 2008. Management strategies in the Czech Telecommunications sector: A comparative study of Český Telecom and T-Mobile. International Journal of Human Resource Management, 19: 2216-2234. 
Sachs, J. D. 1992. Privatization in Russia: some lessons from Eastern Europe. The American Economic Review, 82: 43-48.

Savas, E. S. 1992. Privatization in post-socialist countries. Public Administration Review, 52: 573-581.

Savas, E. 2000. Privatization and public-private partnerships. New York: Chatham House.

Schmitt, C. 2011. What drives the diffusion of privatization policy? Evidence from the telecommunications sector. Journal of Public Policy, 31: 95-117.

Scott, R.W., 1995. Institutions and organizations. Thousand Oaks, CA: Sage.

Silvestre, B., Hall, J., Matos, S., \& Figueira, L. A. 2010. Privatization of electricity distribution in the Northeast of Brazil: The good, the bad, the ugly or the naive? Energy Policy, 38: 7001-7013.

Smith, S. C., Cin, B. C., \& Vodopivec, M. 1997. Privatization incidence, ownership forms, and firm performance: Evidence from Slovenia. Journal of Comparative Economics, 25: 158179.

Somé, H. Y., Cano-Kollmann, M., Mudambi, R., \& Cosset, J. C. (Forthcoming). The effect of privatization on the characteristics of innovation. Financial Management.

Soulsby, A., \& Clark, E. 1996. The emergence of post-communist management in the Czech Republic. Organization Studies, 17: 227-247.

Soulsby, A., \& Clark, E. 2006. Changing patterns of employment in post-socialist organizations in Central and Eastern Europe: management action in a transitional context. International Journal of Human Resource Management, 17:1396-1410.

Spicer, A., McDermott, G. A., \& Kogut, B. 2000. Entrepreneurship and privatization in Central Europe: The tenuous balance between destruction and creation. Academy of Management Review, 25: 630-649.

Spiller, P.T., 1996. Institutions and commitment. Industrial and Corporate Change 5: 421452.

Starr, P. 1988. The meaning of privatization. Yale Law \& Policy Review, 6: 6-41.

Subramanian, K., \& Megginson, W. 2018. Employment protection laws and privatization. The Journal of Law and Economics, 61: 97-123.

Sueyoshi, T. 1998. Privatization of Nippon Telegraph and Telephone: Was it a good policy decision? European Journal of Operational Research, 107: 45-61.

Sun, Q., \& Tong, W. H. 2003. China share issue privatization: the extent of its success. Journal of Financial Economics, 70: 183-222.

The PB Report 2017. A Publication of the Privatization Barometer.

Tian, G. 2000. Property rights and the nature of Chinese collective enterprises. Journal of Comparative Economics, 28: 247-268.

Tyrrall, D., \& Parker, D. 2005. The fragmentation of a railway: a study of organizational change. Journal of Management Studies, 42: 507-537.

Uhlenbruck, K., \& Castro, J. D. 2000. Foreign acquisitions in Central and Eastern Europe: Outcomes of privatization in transitional economies. Academy of Management Journal, 43: 381-402.

Uhlenbruck, N., \& Castro, J. D. 1998. Privatization from the acquirer's perspective: A mergers and acquisitions-based framework. Journal of Management Studies, 35: 619-640.

Vaaler, P. M., \& Schrage, B. N. 2009. Residual state ownership, policy stability and financial performance following strategic decisions by privatizing telecoms. Journal of International Business Studies, 40: 621-641.

Van de Ven, A. H., \& Poole, M. S. 1995. Explaining development and change in organizations. Academy of Management Review, 20: 510-540.

Vickers, J., \& Yarrow, G. 1991. Economic perspectives on privatization. Journal of Economic Perspectives, 5: 111-132. 
Vining, A. R., \& Boardman, A. E. 1992. Ownership versus competition: Efficiency in public enterprise. Public Choice, 73: 205-239.

Wallsten, S. J. 2001. An econometric analysis of telecom competition, privatization, and regulation in Africa and Latin America. Journal of Industrial Economics, 49: 1-19.

Wang, L., \& Judge, W. Q. 2012. Managerial ownership and the role of privatization in transition economies: The case of China. Asia Pacific Journal of Management, 29: 479-498.

Whitley, R., \& Czabán, L. 1998. Institutional transformation and enterprise change in an emergent capitalist economy: The case of Hungary. Organization Studies, 19: 259-280.

Whitley, R., Henderson, J., \& Czaban, L. 1997. Ownership, control and the management of labour in an emergent capitalist economy: the case of Hungary. Organization, 4: 409-432.

Woidtke, T. 2002. Agents watching agents? Evidence from pension fund ownership and firm value. Journal of Financial Economics, 63: 99-131.

Wright, M., Hoskisson, R. E., Busenitz, L. W., \& Dial, J. 2000. Entrepreneurial growth through privatization: The upside of management buyouts. Academy of Management Review, 25: 591-601.

Wu, H. L., Su, W. C., \& Lee, C. Y. 2008. Employee ownership motivation and individual risktaking behaviour: A cross-level analysis of Taiwan's privatized enterprises. The International Journal of Human Resource Management, 19: 2311-2331.

Xia, F., \& Walker, G. 2015. How much does owner type matter for firm performance? Manufacturing firms in China 1998-2007. Strategic Management Journal, 36: 576-585.

$\mathrm{Xu}$, K., Tihanyi, L., \& Hitt, M. A. 2017. Firm resources, governmental power, and privatization. Journal of Management, 43: 998-1024.

Yarrow, G. 1986. Privatization in theory and practice. Economic policy, 1: 323-364.

Zahra, S. A., Ireland, R. D., Gutierrez, I., \& Hitt, M. A. 2000. Introduction to Special Topic Forum Privatization and Entrepreneurial Transformation: Emerging Issues and a Future Research Agenda. Academy of Management Review, 25: 509-52

Zhang, Y. F., Parker, D., \& Kirkpatrick, C. 2008. Electricity sector reform in developing countries: an econometric assessment of the effects of privatization, competition and regulation. Journal of Regulatory Economics, 33: 159-17

\section{NOTES}

1. For a detailed review of the privatization-performance relationship see Megginson \& Netter, 2001; Megginson, 2017 and Bachiller, 2017

2. It is worth noting, however, that these conclusions should be taken with caution, as governments tend to privatize through IPOs the largest and most promising enterprises, and to sell more "problematic" ones through other methods (Estrin \& Pelletier, 2018; Megginson et al., 2005).

3. CMEs, for instance, tend to have higher levels of membership in trade unions, and wage negotiations tend to happen at sectoral or national level. In contrast, workers in LMEs are often less organized, and wages are negotiated individually or at company level. While workers in CMEs tend to have more specific skillsets, tied to the firm or industry they work in, workers in LMEs have more general skillsets, transferable across different firms and industries

4. Only six of the seventeen studies reviewed by Megginson (2017) show solid evidence of improvement in financial performance after privatization, whereas others offer less conclusive evidence, such as improvements limited only to $20 \%$ of the sample (Dinc \& Gupta, 2011) or mostly attributable to financial restructuring prior to sales (Berger et al., 2005). Some of these studies also measure financial performance using relatively short-term changes in stock price, therefore capturing market assumptions and expectations rather the actual impact of privatization on operations (Li et al, 2016; Wolf \& Pollitt, 2008). In fact, several studies published in the same period, but not included in Megginson's review, show either mixed or no improvement (e.g., Alexandre \& Charreaux, 2004; Bozec, Dia, \& Breton, 2006; Feng, Sun, \& Tong, 2004). 


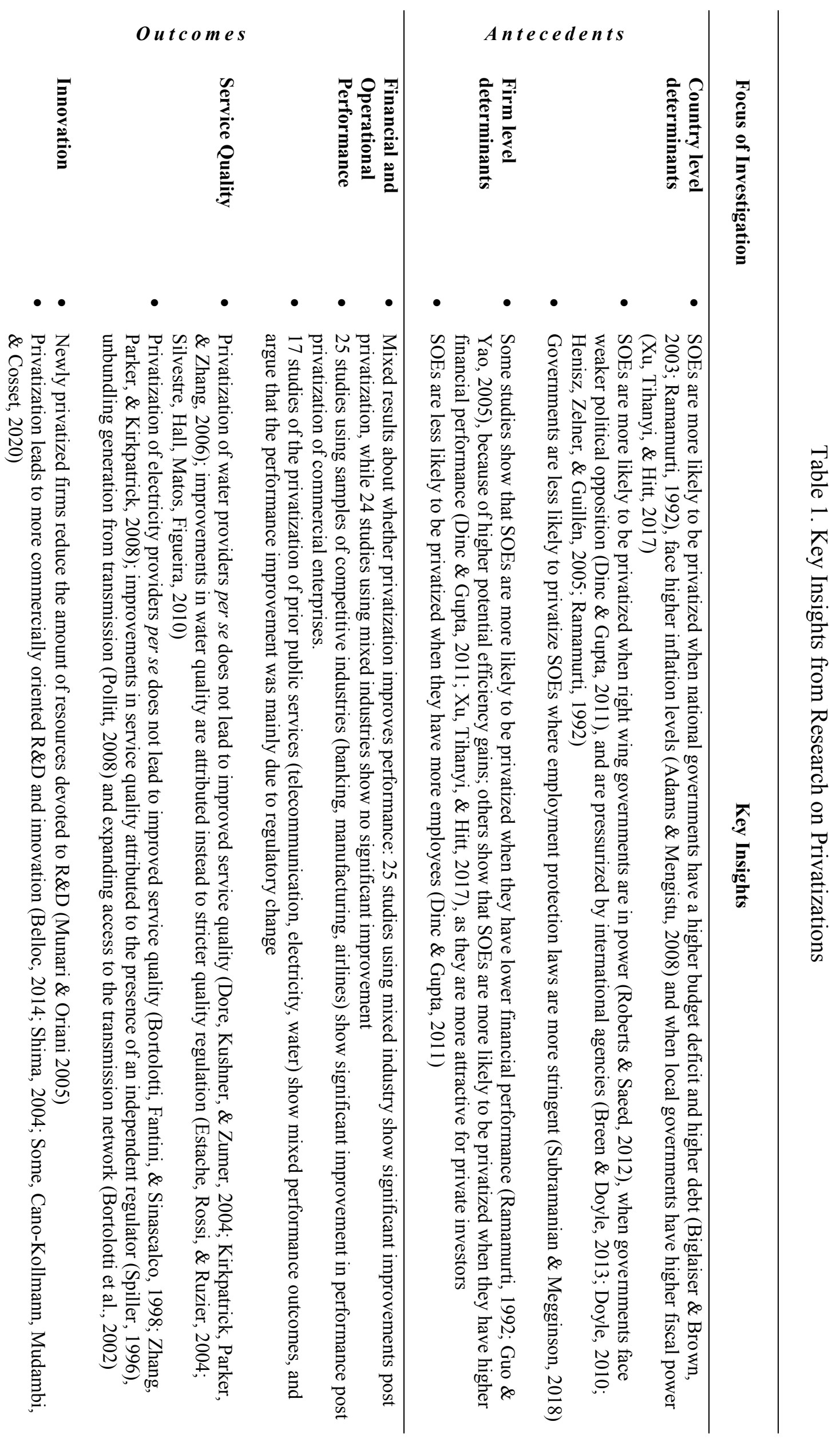




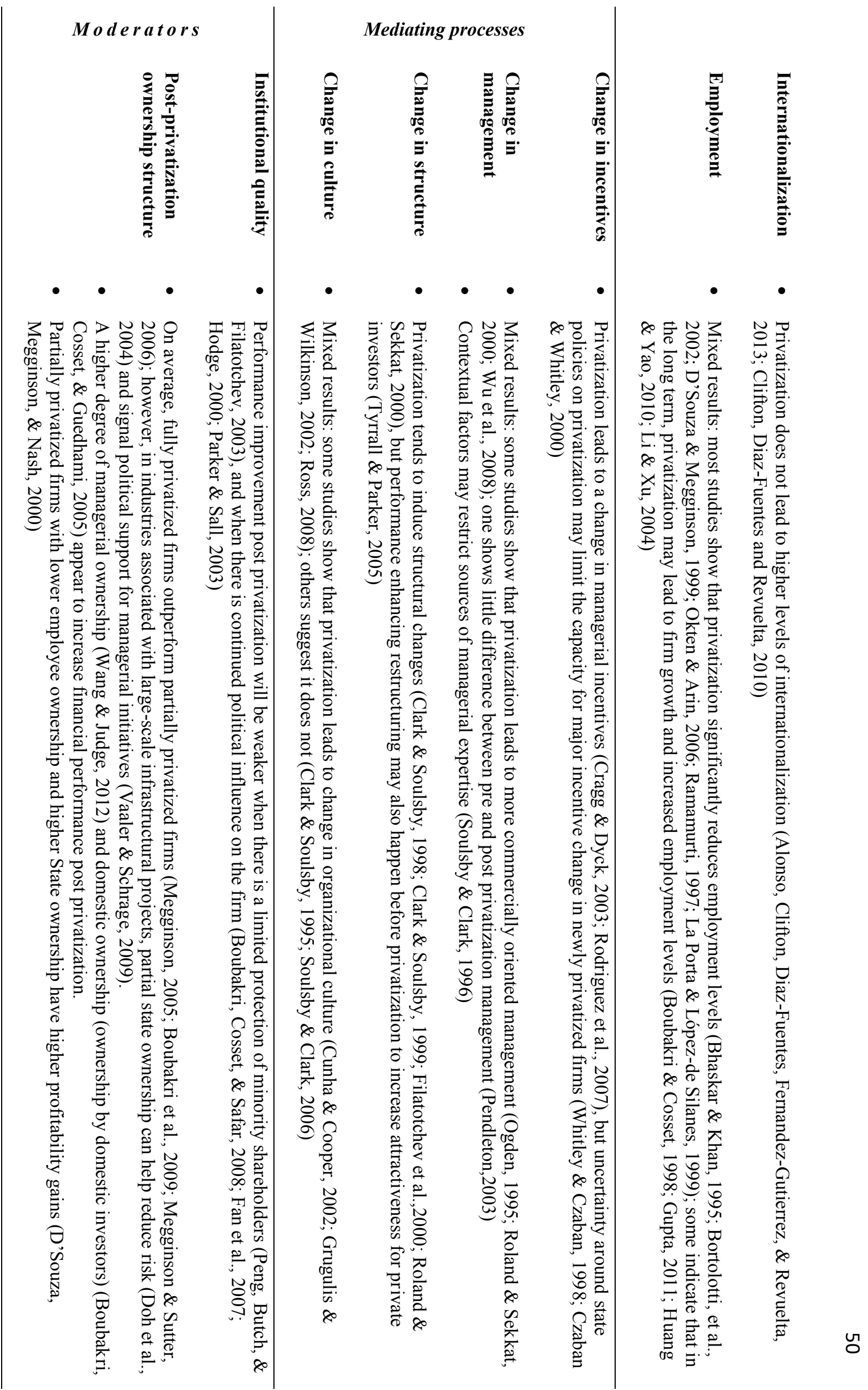




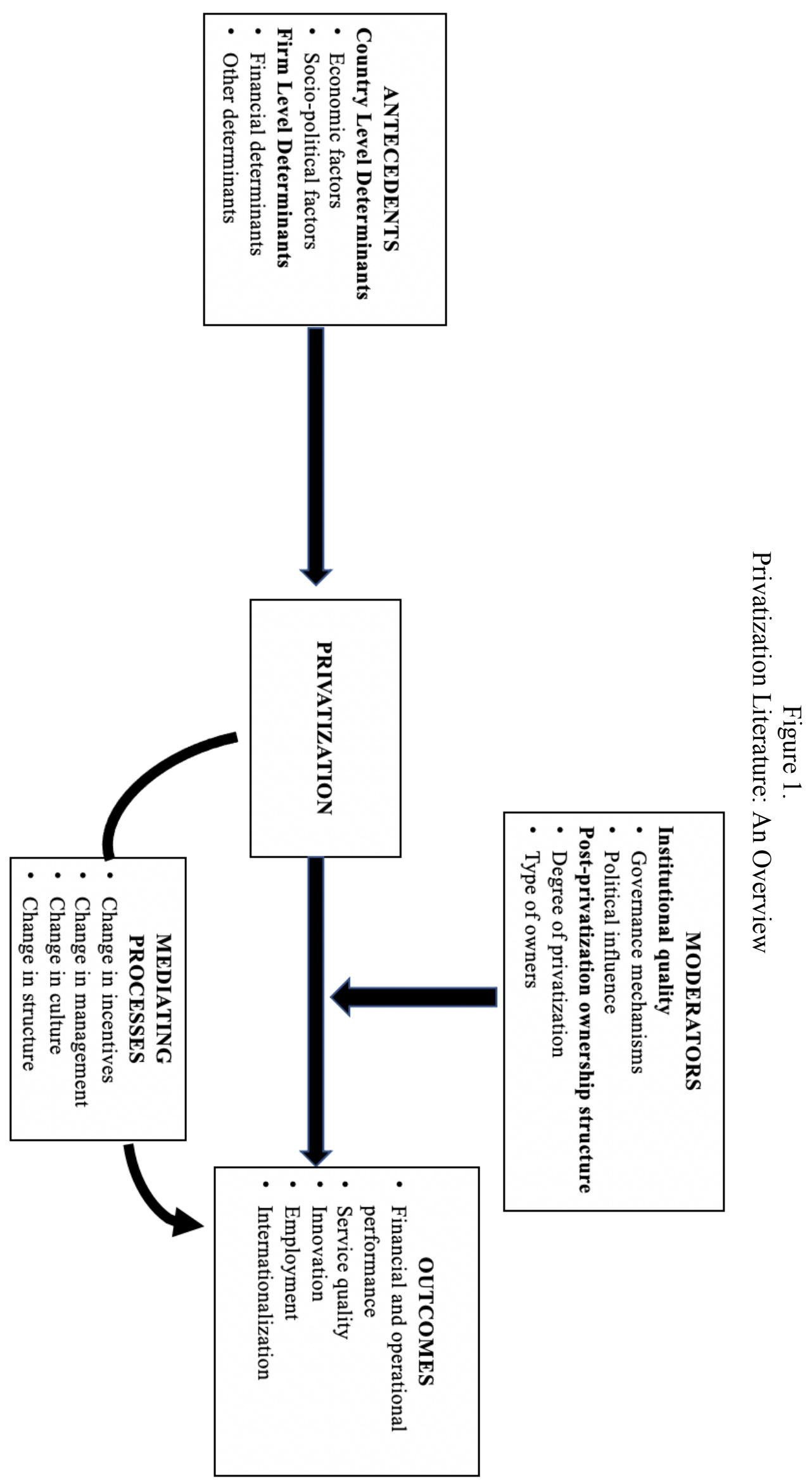

